\title{
The Political Origins of SECTION 13(3) OF THE Federal Reserve Act
}

- When the Federal Reserve made emergency loans to nonbank financial institutions in 2008 in an effort to stem the financial crisis, it did so under the auspices of Section 13(3) of the Federal Reserve Act.

- Section 13(3), added at the height of the Great Depression in 1932, expanded the Fed's emergency-lending authority beyond the financial sector to include a broader set of institutions.

- However, the scale and nature of the 2008 lending activity raise the question of what Congress intended in 1932.

- This detailed analysis of the legislative events and political environment in the years prior to the addition of Section 13(3) leads the author to conclude that the section's original framers meant to endow the Fed with the ability to lend directly to the real economy in an emergency.

\section{INTRODUCTION}

The Federal Reserve resorted to statutory authorities that had lain dormant for more than seven decades when, in 2008, it took steps to bolster a financial system on the brink of collapse. The Fed had been granted these powers in 1932 through passage of the Emergency Relief and Construction Act, which added Section 13(3) to the Federal Reserve Act. Section 13(3) as amended gave Federal Reserve Banks the authority to "discount" for any "individual, partnership, or corporation" notes "indorsed or otherwise secured to the satisfaction of the Federal Reserve Bank $[\mathrm{s}]$,"1 subject to a finding by the Federal Reserve Board (now the Board of Governors of the Federal Reserve System) of "unusual and exigent circumstances."

In 2008, at the height of the financial crisis, the Federal Reserve System used its 13(3) authority to provide loans

${ }^{1}$ Editor's note: This article includes quoted material from numerous source documents. In the interest of readability, we have standardized the capitalization of certain terms (Federal Reserve, Federal Reserve Banks, Federal Reserve System, Federal Reserve notes) in accordance with Economic Policy Review style conventions. The appearance of those terms may vary from the original.

${ }^{2}$ The Emergency Relief and Construction Act of July 21, 1932, 47 Stat. 709 added a third paragraph to Section 13 of the Federal Reserve Act, commonly referred to as Section 13(3). The section was subsequently amended by the acts of August 23, 1935 (49 Stat. 714) and December 19, 1991 (105 Stat. 2386).
At the time this article was written, Parinitha Sastry was a senior research analyst at the Federal Reserve Bank of New York. Currently, she is a graduate student at MIT.

pari.sastry@gmail.com
The author thanks Megan Cohen, Kara Masciangelo, Mary Tao, Julie Sager, Lucy Leggiero, Philip Wallach, the librarians at the Carter Glass Archives at the University of Virginia, and two anonymous referees for help with assembling archival materials and for comments on earlier drafts. The views expressed in this article are those of the author and do not necessarily reflect the position of the Federal Reserve Bank of New York or the Federal Reserve System.

The author declares that she has no relevant or material financial interests that relate to the research described in this article. 
in support of a variety of markets and market participants, including broker-dealers, commercial paper issuers, and money market mutual funds. ${ }^{3}$ The Board of Governors created six emergency facilities, and authorized direct loans to three special purpose vehicles, four broker-dealers, and an insurance company (see Table 1). ${ }^{4}$ Federal Reserve lending under the section peaked at more than $\$ 700$ billion in late 2008, as shown in Chart 1.

The unprecedented variety, scale, and nature of the 13(3) loans and loan facilities raise the question of what Congress intended in 1932. This article explores that question, examining the legislative history of the section and the economic and political environment that influenced congressional views.

The original Federal Reserve Act of December 23, 1913, incorporated strict limits on the scope of discretionary central bank credit policy, and these restrictions were, for the most part, left unchanged in the early years of the Federal Reserve System. Before the 1930s, federal initiatives aimed at mitigating credit market dysfunctions usually involved the creation of government-sponsored enterprises endowed with funds from the U.S. Treasury and given targeted lending authorities (such as the Federal Land Banks). However, in the throes of the Great Contraction (1929-33), Congress turned to the Federal Reserve System, relaxing its statutory strictures and authorizing expansive lending.

Given the nature of other Depression-era credit initiatives, it is not unreasonable to conjecture that Congress added 13(3) to allow for discount window lending to distressed financial intermediaries such as nonmember banks and other financial institutions outside the Federal Reserve System. However, the legislative history and political context of the section suggest a much broader mandate. This article concludes that the framers of the section intended to authorize credit extensions to individuals and nonfinancial businesses unable to get private-sector loans. In other words, Section 13(3) sanctioned direct Federal Reserve lending to the real economy, rather than simply to a weakened financial sector, in emergency circumstances.

The article is organized as follows. Section 2 explores the early history of the Federal Reserve Act, focusing on how the conceptual underpinnings of the act influenced legislative approaches to dysfunction in the credit markets prior to the Great Contraction. The initial political responses to the Great Contraction, which were broadly consistent with the earlier congressional approaches, are discussed in Section 3. Section 4 describes the Glass-Steagall Act of February 1932

\footnotetext{
3 “Congress's Afterthought, Wall Street's Trillion Dollars," Washington Post, May 30, 2009.

${ }^{4}$ Government Accountability Office (2011).
}

as a decisive turning point that initiated a drastic broadening of Federal Reserve lending and note-issuance powers, while Section 5 focuses on Section 13(3) of the Federal Reserve Act, including its legislative origins, usage, and interpretation. Section 6 presents concluding remarks and describes the evolution of Section 13(3) since the Great Contraction.

\section{EARly History}

\subsection{The Conceptual Framework of the Federal Reserve Act}

Any exploration of pre-New Deal banking history requires a sound understanding of two profoundly influential economic ideas: the gold standard and the "real bills" doctrine. Those ideas shaped Congress' understanding of the core function of a central bank and were deeply embedded in the Federal Reserve Act.

The Federal Reserve Act was born out of the wreckage of the Panic of 1907, a crisis that put a spotlight on the adverse consequences of a rigid monetary base. ${ }^{5}$ At the time, the monetary base consisted of gold coin and paper currency that could be redeemed for gold (including gold certificates, U. S. notes, and national bank notes). ${ }^{6}$ Gold in the form of bullion and coin was used in international transactions; paper currency and gold coin were used as media of exchange domestically.

Gold reigned supreme as the anchor for the U.S. monetary system, and all forms of money were convertible into gold at the rate set by the Gold Standard Act of 1900: 25.8 grains of gold, nine-tenths fine, per dollar. ${ }^{7}$ Convertibility was never an issue for gold coins, since gold was physically integrated into every coin. ${ }^{8}$ Gold certificates were no more than warehouse receipts for gold coin or bullion held at the Treasury. ${ }^{9}$

U. S. notes, also called "greenbacks," were one remove away from gold. As dollar-denominated legal tender, they could be redeemed at the Treasury for gold and were backed by a $\$ 150$ million gold reserve fund. ${ }^{10}$ National bank notes were liabilities of the national banks that issued them and were redeemable for lawful money (gold coin, gold certificates,

\footnotetext{
${ }^{5}$ National Monetary Commission report referenced in Friedman and Schwartz (1963, 169); Hepburn $(1908,52)$; Bruner and Carr $(2007,3)$.

${ }^{6}$ Friedman and Schwartz $(1963,2-7)$.

${ }^{7}$ Timberlake $(1978,174)$.

${ }^{8}$ For example, a $\$ 10$ gold coin would have 258 grains of gold, nine-tenths fine.

${ }^{9}$ Garbade $(2012,14)$.

${ }^{10}$ Friedman and Schwartz $(1963,24)$.
} 
TABLE 1

Section 13(3) Facilities and Direct Assistance Authorized in 2008

\begin{tabular}{|c|c|c|}
\hline Announcement Date & Facilities and Direct Assistance & Primary Participants / Beneficiaries \\
\hline March 11 & Term Securities Lending Facility $(\mathrm{TSLF})^{\mathrm{a}}$ & Primary dealers \\
\hline March 14 & $\begin{array}{l}\text { Federal Reserve Bank of New York bridge loan of } \\
\$ 12.9 \text { billion to Bear Stearns via JPMorgan Chase }\end{array}$ & Bear Stearns, JPMorgan Chase \\
\hline March 16 & $\begin{array}{l}\$ 30 \text { billion nonrecourse loan to JPMorgan Chase secured } \\
\text { by Bear Stearns' assets }^{c}\end{array}$ & JPMorgan Chase \\
\hline March 16 & Primary Dealer Credit Facility $(\mathrm{PDCF})^{\mathrm{c}}$ & Primary dealers \\
\hline March 24 & $\begin{array}{l}\text { Federal Reserve Bank of New York senior loan of } \$ 29 \text { billion } \\
\text { to the Maiden Lane LLC vehicle (ML) })^{\mathrm{d}}\end{array}$ & Maiden Lane LLC, Bear Stearns \\
\hline September 16 & $\begin{array}{l}\text { Federal Reserve Bank of New York revolving credit facility of } \\
\text { up to } \$ 85 \text { billion for the American Insurance Group (AIG) }\end{array}$ & AIG \\
\hline September 19 & $\begin{array}{l}\text { Asset-Backed Commercial Paper Money Market Mutual } \\
\text { Fund Liquidity Facility (AMLF) }^{\mathrm{e}}\end{array}$ & $\begin{array}{l}\text { U.S. depository institutions and U.S. bank holding } \\
\text { companies (parent companies or U.S broker-dealer } \\
\text { affiliates) and U.S. branches and agencies of foreign banks }\end{array}$ \\
\hline September 21 & $\begin{array}{l}\text { Federal Reserve Bank of New York loan to London-based } \\
\text { broker-dealer subsidiaries of Goldman Sachs, Morgan Stanley, } \\
\text { and Merrill Lynch. }\end{array}$ & $\begin{array}{l}\text { London-based subsidiaries of Goldman Sachs, } \\
\text { Morgan Stanley, and Merrill Lynch }\end{array}$ \\
\hline October 7 & Commercial Paper Funding Facility $(\mathrm{CPFF})^{\mathrm{e}}$ & U.S. commercial paper issuers \\
\hline October 8 & $\begin{array}{l}\text { Arrangement allowing the Federal Reserve Bank of } \\
\text { New York to borrow up to } \$ 37.8 \text { billion in securities } \\
\text { from certain subsidiaries of } \mathrm{AIG}^{\mathrm{e}}\end{array}$ & Certain U.S. insurance subsidiaries of AIG \\
\hline October 21 & Money Market Investor Funding Facility $(\mathrm{MMIFF})^{\mathrm{e}}$ & U.S. money market mutual funds \\
\hline November 10 & $\begin{array}{l}\text { Federal Reserve Bank of New York loan of up to } \$ 22.5 \text { billion } \\
\text { to Maiden Lane II LLC in support of AIG (MLII) }\end{array}$ & Maiden Lane II LLC, AIG \\
\hline November 10 & $\begin{array}{l}\text { Federal Reserve Bank of New York loan of up to } \$ 30 \text { billion to } \\
\text { Maiden Lane III LLC in support of AIG (MLIII) }\end{array}$ & Maiden Lane III LLC, AIG \\
\hline November 23 & $\begin{array}{l}\text { Federal Reserve commitment to provide a nonrecourse } \\
\text { loan to Citigroup }\end{array}$ & Citigroup \\
\hline November 23 & $\begin{array}{l}\text { Federal Reserve Bank of New York loan to London-based } \\
\text { broker-dealer subsidiary of Citigroup }\end{array}$ & London-based subsidiary of Citigroup \\
\hline November 25 & Term Asset-Backed Securities Loan Facility (TALF) ${ }^{\mathrm{e}}$ & "All U.S. persons with eligible collateral"" \\
\hline
\end{tabular}

${ }^{a}$ Board of Governors of the Federal Reserve System, “Credit and Liquidity Programs and the Balance Sheet," 2010, https://www.federalreserve.gov/ monetarypolicy/bst_lendingprimary.htm (last updated on October 27, 2016; accessed August 24, 2017).

${ }^{\mathrm{b}}$ Board of Governors of the Federal Reserve System, “Bear Stearns, JPMorgan Chase, and Maiden Lane LLC,” 2013, https://www.federalreserve.gov/ regreform/reform-bearstearns.htm (last updated on February 12, 2016; accessed August 24, 2017).

${ }^{\mathrm{C}}$ Geithner (2008). The $\$ 30$ billion nonrecourse loan to JPMorgan Chase was replaced by the March 24, 2008, loan agreement.

${ }^{\mathrm{d}}$ Federal Reserve Bank of New York (2008). The Maiden Lane LLC facility closed on June 26, 2008.

${ }^{\mathrm{e}}$ Board of Governors of the Federal Reserve System, press releases dated September 16, 19, and 21, 2008; October 7, 8, and 21, 2008; and November 10 and 25, 2008; https://www.federalreserve.gov/newsevents/pressreleases.htm. Legal authorization can be found in "Terms and Conditions." The September and October loans to AIG were replaced by the November 10, 2008, facilities. On October 3, 2008, the Federal Reserve Board authorized the Direct Money Market Mutual Fund Lending Facility (DMLF) and rescinded this authorization one week later. DMLF was never implemented.

${ }^{\mathrm{f}}$ Authorization to Provide Residual Financing to Citigroup, Inc. for a Designated Asset Pool. See Board of Governors of the Federal Reserve System (2008). This was part of a package of coordinated actions by the Treasury Department, the Federal Deposit Insurance Corporation (FDIC), and the Federal Reserve. The Federal Reserve loan was never called upon. The Fed negotiated a similar commitment to provide a nonrecourse loan to Bank of America under 13(3) if necessary in January 2009, but the agreement was never finalized. See Board of Governors of the Federal Reserve System (2009).

g Board of Governors of the Federal Reserve System, minutes, November 23, 2008, page 31. Available at https://www.federalreserve.gov/newsevents/ pressreleases/files/monetary20090311al.pdf. 
CHART 1

Section 13(3) Loans in 2008

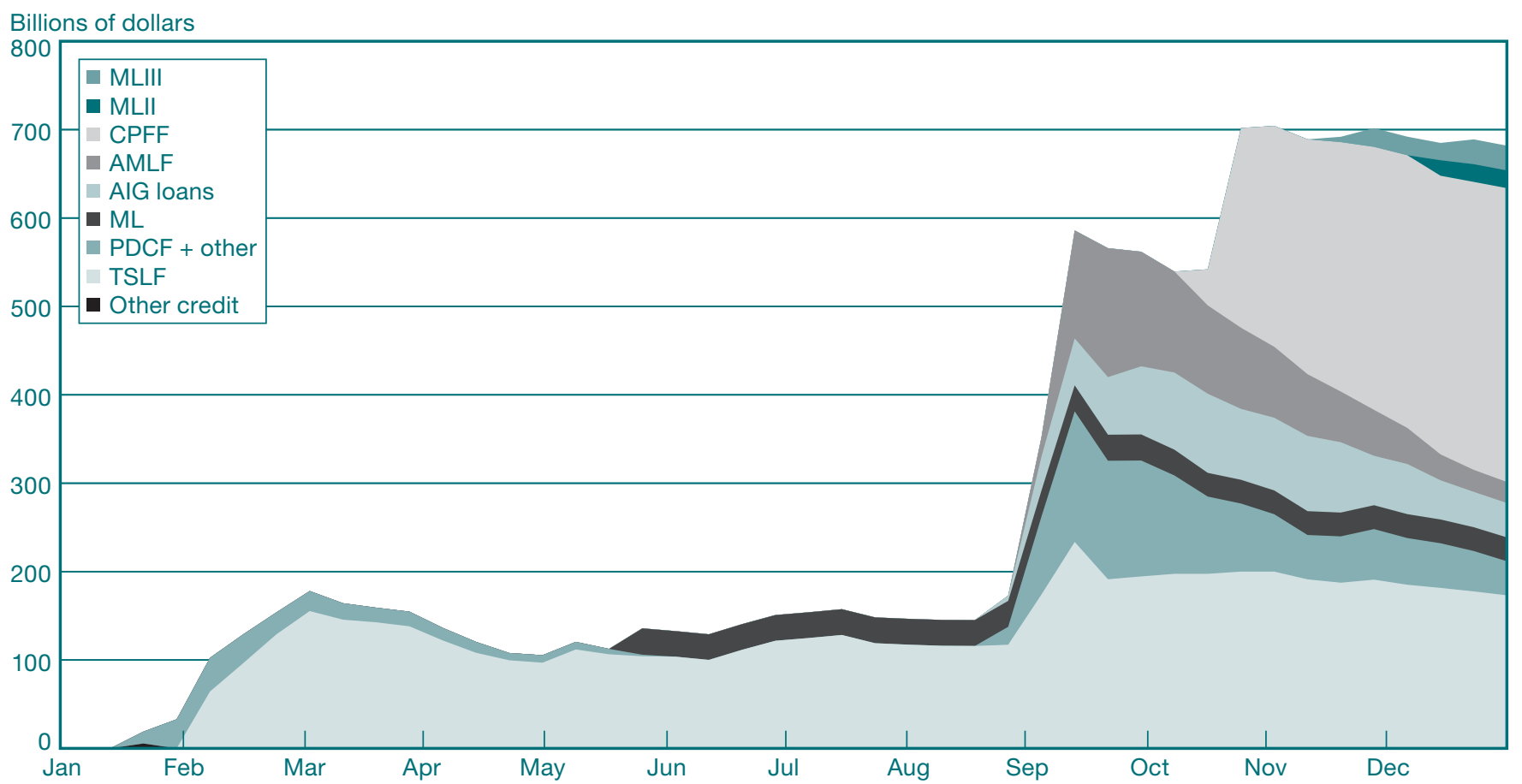

Source: Federal Reserve Board H.4.1 Release, Factors Affecting Reserve Balances.

Notes: Figures reflect weekly averages. TSLF is Term Securities Lending Facility. PDCF is Primary Dealer Credit Facility. ML is Maiden Lane LLC vehicle. AMLF is Asset-Backed Commercial Paper Money Market Mutual Fund Liquidity Facility. CPFF is Commercial Paper Funding Facility. MLII is Maiden Lane II LLC in support of AIG. MLIII is Maiden Lane III LLC in support of AIG. TALF is Term Asset-Backed Securities Loan Facility.

and U.S. notes) on demand at the bank of issue or at the U.S. Treasury. ${ }^{11}$ The notes were backed 100 percent by government bonds as well as by a redemption fund of lawful money equal to 5 percent of the value of notes outstanding. Although national bank notes were not lawful money, they were widely accepted as equivalent to currency issued by the U.S. government. ${ }^{12}$

Of the three major components of the monetary base (gold, U.S. notes, and national bank notes), only the supply of gold could expand significantly seasonally or in a crisis. ${ }^{13}$

\footnotetext{
${ }^{11}$ Friedman and Schwartz $(1963,20)$.

${ }^{12}$ Friedman and Schwartz $(1963,21)$. National bank notes could not, however, be used to meet reserve requirements for national banks.

${ }^{13}$ Eichengreen $(1992,55)$. The U.S. Treasury could influence the supply of high-powered money by moving Treasury gold reserves from its vaults into and out of banks. However, the Treasury's monetary tools were limited during the Panic of 1907, as Friedman and Schwartz $(1963,162)$ show. The Treasury's available balance totaled just $\$ 5$ million, and the Treasury did issue debt with the intent of providing the national banks with assets they could use to back their note issue, but those efforts were too small to offset the decline in the money stock in 1907.
}

The supply of U.S. notes was fixed by statute at $\$ 347$ million. ${ }^{14}$ National bank note issuance could, in theory, vary in response to economic shocks but was more likely to expand in response to procyclic profit opportunities. ${ }^{15}$ Gold, however, could vary as a result of net exports and capital flows. ${ }^{16}$

This relatively rigid monetary base could not easily accommodate the large seasonal swings in demand for money and credit emanating from the agricultural sector of the U.S. economy. Every fall, farmers needed cash to pay field hands, and commodity merchants needed credit to purchase and carry harvest inventories or, to use the terminology of the time, "move the crops." ${ }^{17}$ Banks' excess reserves would shrink

\footnotetext{
${ }^{14}$ Friedman and Schwartz $(1963,24)$.

${ }^{15}$ Friedman and Schwartz (1963, 21 and 182); Calomiris and Mason (2008, 331). The volume of government securities bearing the circulation privilege did technically limit national bank note issuance, but this constraint was not binding until the 1920s.

${ }^{16}$ Timberlake (1978, 181); Friedman and Schwartz $(1963,169)$.

${ }^{17}$ Kemmerer (1910, 218).
} 
in response to the increased demand for cash and credit, triggering a surge in interest rates. ${ }^{18}$ Even minor disruptions to the financial system during intervals of such seasonal strain could escalate rapidly to a perilous financial crisis. ${ }^{19}$ Later, during the winter, merchants would pay back their loans from the receipts on exports and final sales to consumers, currency and coin paid to field hands would find its way into circulation, and interest rates would subside. ${ }^{20}$

\section{An Elastic Monetary Base}

The framers of the Federal Reserve Act sought to accommodate the seasonal variation in demand for cash and credit by providing a more elastic monetary base, which they believed would bring about more elasticity of credit and hence help stem the problem of banking crises. ${ }^{21}$ Their solution was to create a Federal Reserve System whose liabilities-Federal Reserve notes and member bank reserve deposits held at Federal Reserve Banks-would displace two of the three components of the monetary base: gold and national bank notes. Gold previously dispersed across private banks was to be centralized within the Federal Reserve System as a reserve against the note and deposit liabilities of the Reserve Banks, and national bank notes were to be replaced by Federal Reserve notes. ${ }^{22}$ There was no intention of displacing U.S. notes, which were a statutorily fixed component of the monetary base.

The new monetary base could vary with seasonal requirements because Federal Reserve Banks could expand and contract their balance sheets by discounting the "real bills" of member banks. ${ }^{23}$ Real bills can be defined broadly

\footnotetext{
${ }^{18}$ Kemmerer $(1910,173)$ writes: "In the fall months a greater burden of work is imposed upon the money in circulation, and, unless its rate of turnover increases, the same amount will not do the work except at a lower level of prices. This extra burden of exchange work is carried in part, we have seen, by the expansive power of deposit currency, but even deposit currency must be supported by cash reserves, and the need of cash for crop-moving purposes, which results in the westward and southward movement of reserve money, limits the expansive power of deposit currency. To meet the crop-moving demand for cash, banks accordingly are compelled to curtail their loans and advance interest rates-both of which measures tend to force down the prices of securities and commodities, particularly those of a speculative character which are dealt in on the exchanges." Calomiris and Gorton (1991) examine this empirically.

${ }^{19}$ Sprague (1910, 16-17).

${ }^{20}$ Kemmerer (1910, 29 and 222).

${ }^{21}$ Calomiris (2013, 170-171).

${ }^{22}$ Garbade $(2012,26)$.

${ }^{23}$ Federal Reserve Act of December 23, 1913, 38 Stat. 251, Section 13. The law compelled all national banks to become members of the Federal
}

as short-term, "self-liquidating" instruments used to finance a step in the process of converting raw materials to final sales. $^{24}$ They were considered to be self-liquidating because they could be repaid with the proceeds of goods sold..$^{25}$ For example, a furniture manufacturer might finance the purchase of $\$ 100$ of raw materials from a supplier with a note promising to pay in thirty days, once the furniture has been produced and sold. The manufacturer's note is a "real bill." The supplier has not lent money to the manufacturer but has delivered $\$ 100$ worth of goods with the expectation of being paid in thirty days. "Discounting" entails the purchase of such bills for the discounted value of the paper. ${ }^{26}$ Continuing with the same example, if the supplier desires funds before the thirty-day period ends, the supplier can bring the manufacturer's note to a commercial bank for discount. In turn, the commercial bank can discount the manufacturer's note with its district Federal Reserve Bank. Upon maturity, the commercial bank pays the Federal Reserve Bank $\$ 100$ and collects $\$ 100$ from the manufacturer. $^{27}$

The real bills discount authority allowed Federal Reserve notes and member-bank reserve deposits to vary with seasonal trade requirements because banks experiencing unusual demands for cash or credit could discount their bills to obtain high-powered money. ${ }^{28}$ Thus, the monetary base would automatically expand during periods of increased commercial activity and contract during slack periods. ${ }^{29}$

Footnote 23 (continued)

Reserve System but left the decision voluntary for state-chartered banks and trusts. State banks and trusts that chose to remain outside the Federal Reserve System were referred to as "nonmember banks and trusts."

${ }^{24}$ Hackley $(1973,31)$. An instrument acceptable for discount-or "eligible paper" - was specifically defined by the Federal Reserve Board as "a bill the proceeds of which have been used or are to be used in producing, purchasing, carrying, or marketing goods in one or more steps of the process of production, manufacture, and distribution" (Federal Reserve Bank of New York Circular No. 25, July 19, 1915).

${ }^{25}$ Hackley $(1973,29)$.

${ }^{26}$ Mengle (1993, 23). For example, a transaction in which the commercial bank receives $\$ 99.75$ for a thirty-day bill with a face value of $\$ 100$ reflects a discount rate of 3 percent (per annum).

${ }^{27}$ Board of Governors of the Federal Reserve System, 1915 Annual Report, p. 161 describes the process: "A few days before maturity each piece of paper is sent for collection to the bank which rediscounted it and on the day of maturity is charged to its account."

${ }^{28}$ High-powered money, or the monetary base, refers to the assets that banks can use as reserves for their deposit liabilities. Federal Reserve Act of December 23, 1913, 38 Stat. 251. Section 13 provides the Fed's discount authority, and Section 16 provides the Fed's note-issuance authority.

${ }^{29}$ Mints $(1945,9)$. Meltzer $(2003,729)$ notes that adherence to the real bills doctrine gives rise to a procylical expansion of money and credit, with the stock of money expanding and contracting alongside output. This result would become manifest during the Great Depression. 
Although the framers likely expected that discounts of real bills would constitute a large portion of Federal Reserve Bank assets, they also allowed Reserve Banks to discount short-term member bank loans secured by Treasury securities and to hold Treasury securities outright. ${ }^{30}$ The authority to purchase government bonds in the open market was intended to be an investment authority. These authorities were of minimal importance at the time the act was passed; Treasury securities outstanding amounted to slightly less than $\$ 1$ billion, and more than 80 percent of that total was pledged by national banks as collateral against national bank notes or Treasury deposits. ${ }^{31}$ The original Federal Reserve Act did not authorize Federal Reserve advances-that is, the lending of money secured by collateral—to member banks. ${ }^{32}$

\section{Limiting the Monetary Base}

The Federal Reserve Act mandated that each dollar of Federal Reserve notes be backed by at least 40 cents in gold and that each dollar of Federal Reserve deposit liabilities be backed by at least 35 cents in gold or lawful money, the latter being convertible into gold at the Treasury. ${ }^{33}$ Since (barring new discoveries) gold was in fixed supply worldwide, the gold reserve requirement served to check secular inflation-that is, prolonged periods of increases in the price level-by constraining the monetary base.

\footnotetext{
${ }^{30}$ Federal Reserve Act of 1913. Paragraph 2 of Section 13 provides the Fed's authority to discount member bank loans secured by Treasury securities, and Sections 14(a)-(b) provide the purchase authority. Sprague $(1914,246)$ discusses the purchase authority: "The purchase and sale of government bonds and notes and state and local short-term obligations require no detailed consideration. In periods of inactive demand for rediscounts, investments of this kind will doubtless be made by the Reserve Banks in order to employ surplus funds." Chandler (1958) discusses how the individual Federal Reserve Banks "discovered" the power of open market operations following World War I when trying to replenish their earnings by investing in government securities.

${ }^{31}$ Garbade $(2012,31)$. Numbers cited represent the amounts outstanding and pledged as of June 30, 1914.

${ }^{32}$ Hackley $(1973,83)$.

${ }^{33}$ Federal Reserve Act of 1913, Section 16, Paragraphs 2-3. "Such application shall be accompanied with a tender to the local Federal Reserve agent of collateral in amount equal to the sum of the Federal Reserve notes thus applied for and issued pursuant to such application. The collateral security thus offered shall be notes and bills, accepted for rediscount under provisions of section thirteen of this Act. . . Every Federal Reserve Bank shall maintain reserves in gold or lawful money of not less than thirty-five per centum against its deposits and reserves in gold of not less than forty per centum against its Federal Reserve notes in actual circulation."
}

The gold reserve requirement was intimately related to the United States' commitment to a gold standard. Federal Reserve deposit liabilities could be converted into Federal Reserve notes, and the notes could be brought to the Treasury and redeemed for gold, or brought to any Federal Reserve Bank and redeemed for gold or lawful money. ${ }^{34}$ Maintaining a gold reserve against Federal Reserve liabilities was essential for ensuring confidence in the convertibility of those liabilities into gold. ${ }^{35}$

\section{Distinguishing between the Two Components of the Monetary Base: Currency and Reserves}

Milton Friedman and Anna Schwartz note that member bank reserve deposits and Federal Reserve notes "have always been interconvertible for banks and hence essentially equivalent, both as liabilities of the Federal Reserve System and in their function as high-powered money." ${ }^{36}$ However, the framers of the Federal Reserve Act did not treat the two liabilities identically, most noticeably with respect to the disparate gold reserve requirements: 40 percent for notes compared with 35 percent for deposits. Additionally, the act required each dollar of Federal Reserve notes to be backed by one dollar of real bills but did not place any real bills requirement on member bank reserves. ${ }^{37}$ Friedman and Schwartz observe that

\footnotetext{
${ }^{34}$ Federal Reserve Act of 1913, Section 16, Paragraph 1 states: "Federal Reserve notes, to be issued at the discretion of the Federal Reserve Board for the purpose of making advances to Federal Reserve Banks through the Federal Reserve agents as hereinafter set forth and for no other purpose, are hereby authorized. The said notes shall be obligations of the United States and shall be receivable by all national and member banks and Federal Reserve Banks and for all taxes, customs, and other public dues. They shall be redeemed in gold on demand at the Treasury Department of the United States, in the city of Washington, District of Columbia, or in gold or lawful money at any Federal Reserve Bank."

${ }^{35}$ Before the passage of the Federal Reserve Act, the Wall Street Journal argued that the pending legislation should "provide for the redemption of the proposed Federal Reserve notes in gold," rather than in both gold and lawful money, because doing the latter "allowed one form of I.O.U. [to] be redeemed in another form of I.O.U." The Journal acknowledged that the Gold Standard Act required that U.S. notes be "kept at parity with gold through the ability of the Government to redeem them in gold" but argued that U.S. notes were "only covered in part (that is to say, against the $\$ 345,581,016$ of greenbacks and the $\$ 2,633,000$ of Treasury notes still outstanding, there is $\$ 150,000,000$ in gold) and the time may come when the Government may have to have recourse to its credit by issuing more bonds in order to meet any extraordinary run on its gold reserve" ("Money," Wall Street Journal, September 19, 1913).

${ }^{36}$ Friedman and Schwartz $(1963,195)$.

${ }^{37}$ Paragraphs 2-3 of Section 16 of the Federal Reserve Act provide the collateral requirements for Federal Reserve notes.
} 
while the gold reserve requirement limited the total stock of money, the real bills requirement involved the "division of the total stock of money between currency and deposits." ${ }^{38}$

The framers of the Federal Reserve Act required Federal Reserve Banks to collateralize their note issues with real bills in hopes of creating a dollar-for-dollar link between bills discounted and notes issued. ${ }^{39}$ Proponents of the real bills doctrine believed that if currency were backed 100 percent by short-term commercial bills, then the supply of currency would be exactly sufficient to purchase the economy's real output at existing prices and thus be neither inflationary nor deflationary. ${ }^{40}$

Reflecting that belief, the architects of the Federal Reserve System focused on currency as the principal driver of monetary expansion and paid less attention to the role played by member bank reserve deposits. ${ }^{41}$ Senator James Reed, Democrat from Missouri, captured the congressional view when in 1913 he stated that "no currency is elastic unless it will stretch far enough to exactly meet the needs of the country," but if it stretched "beyond that," it would be "a very dangerous thing, because it would mean inflation." ${ }^{42}$ In the same vein, Paul Warburg, a framer of the Federal Reserve Act and the second Governor of the Federal Reserve Board, cautioned against using "government bonds or other permanent investments as a basis for note issue" because it would be "unscientific and dangerous" and would lead to "inflation based on the requirements of government without connection of any kind with the temporary needs of the toiling nation." ${ }^{43}$ Meltzer (2003) notes that these views were mistaken because "it is the total quantity of notes, not their backing, that affects the price level" and because they ignore the role played by bank reserves. ${ }^{44}$

\footnotetext{
${ }^{38}$ Friedman and Schwartz $(1963,192)$.

${ }^{39}$ Section 13 of the Federal Reserve Act provides the Fed's discount powers.

${ }^{40}$ Humphrey $(1982,4)$; Glass $(1927,274)$.

${ }^{41}$ For more discussion on this matter, see Friedman and Schwartz $(1963,169)$.

${ }^{42}$ Committee on Banking and Currency $(1913,1306)$

${ }^{43}$ Warburg (1910, 37).

${ }^{44}$ Meltzer $(2003,56)$. The framers' belief that the real bills doctrine prevents inflation is problematic for two main reasons. First, the real bills doctrine affected Federal Reserve note issuance but placed no limits on the expansion of the money stock through member bank reserves. Second, the real bills doctrine actually allowed for unlimited Federal Reserve note issuance. Those who subscribed to the real bills doctrine did not recognize that the nominal value of real bills depends upon the prices of goods, which are in turn determined by the money stock. Since the demand for loans depends on the prevailing price level as well as the volume of real transactions, the supply of real bills can increase directly in response to increased prices, which can lead to increased currency issuance if such real bills are brought for discount to the Federal Reserve and used to back Federal Reserve notes.
}

The Federal Reserve Act provided for an elastic monetary base backed by real bills, but it was the gold reserve requirement-not real bills-that checked secular inflation. ${ }^{45}$ As Friedman and Schwartz observe, "the real bills criterion sets no effective limits to the quantity of money." ${ }^{\prime 6}$ Regardless, such beliefs played a crucial role in congressional debates about Federal Reserve note-issuance powers after World War I.

The real bills doctrine constrained congressional thinking for almost two decades following the creation of the Federal Reserve System. Congress created the System to fashion an "elastic currency" within the limits of a gold standard, and provided the Reserve Banks with limited discounting powers that were directly linked to their monetary powers. With the exception of bank loans secured by Treasury securities, the legal restriction on what the Federal Reserve System could discount (real bills) was intimately related to what assets could back Federal Reserve currency (real bills). ${ }^{47}$ The currency-issuing function defined the Federal Reserve's role in financial markets, and no thought was given to the Federal Reserve as a credit institution.

\section{Violations of the Real Bills Doctrine}

Prior to the Great Contraction, Congress departed from the tenets of the real bills doctrine on two occasions, the first departure minor, the second major.

On September 7, 1916, before U.S. involvement in World War I, Congress amended the Federal Reserve Act to allow fifteen-day advances to member banks on the banks' promissory notes secured either by Treasury securities or by

\footnotetext{
${ }^{45}$ The gold constraint was not thought to be binding at the time the Federal Reserve Act was passed. As O.M.W. Sprague, Harvard economist and highly respected scholar, commented in 1914, "The circumstances are hardly conceivable in which a Reserve Bank would not have an amount of gold in its entire reserve ample to provide a gold reserve for such notes as it might issue" (Sprague 1914, 240).

${ }^{46}$ Friedman and Schwartz $(1963,191)$.

${ }^{47}$ Friedman and Schwartz $(1963,192)$ summarized: "The Federal Reserve System was created by men whose outlook on the goals of central banking was shaped by their experience of money panics during the national banking era. The basic monetary problem seemed to them to be banking panics produced by or resulting in an attempted shift by the public from deposits to currency. In order to prevent such shifts from producing either widespread bank failures or the restriction of cash payments by banks, some means were required for converting deposits into currency without a reduction in the total of the two. This in turn required the existence of some form of currency that could be rapidly expanded-to be provided by the Federal Reserve note-and some means of enabling banks to convert their assets readily into such currency-to be the role of discounting."
} 
any asset that was eligible for discount. ${ }^{48}$ Many observers recognized that allowing fifteen-day advances to be secured by Treasury securities conflicted with the real bills doctrine. For example, A.D. Welton, a commercial banker from Chicago, wrote in 1925 that "The making of loans against government bonds . . . is really a distortion of the purposes of the [Federal Reserve] Act." ${ }^{39}$ However, the advances authority was of limited importance since, in 1916, Treasury debt issuance was minimal and most outstanding Treasury debt was pledged by national banks as collateral for national bank note issues and Treasury deposits..$^{50}$ At the time, the advances authority was viewed as an administrative matter that simplified Federal Reserve operations. ${ }^{51}$ Moreover, Congress stipulated that the fifteen-day loans could not be used to back Federal Reserve notes. ${ }^{52}$ So the overall effect of this departure from the real bills doctrine was minor.

The more significant departure came the following year, after the U.S. declaration of war against Germany on April 6, 1917. On June 21, 1917, Congress amended the Federal Reserve Act's note-issuance provisions in two ways, each of which constituted a material violation of the real bills doctrine. First, it reduced the total amount of collateral needed to back Federal Reserve notes, requiring only enough real bills to back that portion of Federal Reserve note liabilities not backed by gold, with the 40 percent minimum gold requirement preserved. ${ }^{53}$ This change severed the

\footnotetext{
${ }^{48}$ The act of September 7, 1916, 39 Stat 752 amended the Federal Reserve Act by adding this paragraph to Section 13: "Any Federal Reserve Bank may make advances to its member banks on their promissory notes for a period not exceeding fifteen days at rates to be established by such Federal Reserve Banks, subject to the review and determination of the Federal Reserve Board, provided such promissory notes are secured by such notes, drafts, bills of exchange, or bankers' acceptances as are eligible for rediscount or purchase by Federal Reserve Banks under the provisions of this Act, or by the deposit or pledge of bonds or notes of the United States."

${ }^{49}$ Welton $(1925,70)$.

${ }^{50}$ Garbade $(2012,31)$.

${ }^{51}$ Hackley $(1973,85)$.

${ }^{52}$ The act of September 7, 1916, did, however, broaden the collateral requirements for Federal Reserve notes slightly by allowing any real bills that were purchased under Section 14 authorities to collateralize Federal Reserve notes. Earlier, only real bills that had been discounted under Section 13 authorities could be used to back Federal Reserve notes. Specifically, Section 16 was amended to read: "The collateral security thus offered shall be notes, drafts, bills of exchange, or acceptances rediscounted under the provisions of section thirteen of this Act, or bills of exchange indorsed by a member bank of any Federal Reserve District and purchased under the provisions of section fourteen of this Act, or bankers' acceptances purchased under the provisions of said section fourteen."

${ }^{53}$ Act of June 21, 1917, 40 Stat. 232. Section 7 of the act of June 21, 1917, amended the second paragraph of Section 16 of the Federal Reserve Act to read: "Such application shall be accompanied with a tender to the local
}

dollar-for-dollar link between real bills and Federal Reserve notes that had been contemplated by the framers of the act. Second, Congress removed the restriction preventing fifteen-day advances from backing Federal Reserve notes.

The June 21 act was passed shortly after the issuance of the first Liberty Loan on June 15, 1917, in which the Treasury floated $\$ 2$ billion of thirty-year bonds, an amount so large that the national banks could not absorb the entirety of the offering. ${ }^{54}$ Given the near-simultaneous passage of the act and issuance of the first Liberty Loan, Congress may have been trying to incentivize the purchase of Treasury securities to help finance the war. Allowing fifteen-day advances to back Federal Reserve notes may have been an attempt to make Treasury securities a more attractive investment for member banks.

Aside from these violations of the real bills doctrine brought about by the exigencies of World War I, the statutory provisions of the Federal Reserve Act relating to the real bills doctrine (specifically, those pertaining to assets eligible for discount and assets that could back Federal Reserve notes) remained intact in the decade leading up to the Great Contraction. By many measures, the new monetary system created by the Federal Reserve Act achieved its stated goals, with dramatically reduced seasonal variation in interest rates and the availability of credit. ${ }^{55}$ However, contrary to what the founders had hoped, an elastic currency backed by real bills did not solve the problem of banking panics - a result that would ultimately become painfully apparent.

\subsection{The First Government-Sponsored Enterprises}

As described earlier, the Federal Reserve Act was born out of the wreckage of the Panic of 1907. The enactment of that legislation altered the landscape of American finance in many ways, with the most dramatic change being the restructuring of the country's monetary system. However, the panic also elevated

Footnote 53 (continued)

Federal Reserve agent of collateral in amount equal to the sum of the Federal Reserve notes thus applied for and issued pursuant to such application. The collateral security thus offered shall be notes, drafts, bills of exchange, or acceptances acquired under the provisions of section thirteen of this Act, or bills of exchange indorsed by a member bank of any Federal Reserve District and purchased under the provisions of section fourteen of this Act, or bankers' acceptances purchased under the provisions of section fourteen, or gold or gold certificates" (emphasis added)

${ }^{54}$ Garbade $(2012,64)$.

${ }^{55}$ Calomiris (2013) reviews the econometric evidence to this effect. 
another long-standing problem in financial markets to a congressional priority: dysfunction in agricultural credit markets. The Country Life Commission, established by President Theodore Roosevelt in 1908 to investigate the quality of farm life, identified a "lack of any adequate system of agricultural credit whereby the farmer may readily secure loans on fair terms. ${ }^{36}$ The commission determined that the high interest rates paid by farmers-far higher than those paid by industrial corporations, railroads, and municipalities-were evidence of problems that merited congressional attention. ${ }^{57}$

Congress responded to the perceived problems by creating new federal credit intermediaries. At the time that the commission submitted its report, in 1910, financial markets were made up of private lenders. ${ }^{58}$ By the time Herbert Hoover assumed the presidency in 1929, Congress had created three government-sponsored enterprises (GSEs) that either directly or indirectly targeted frictions in agricultural credit markets: (1) the Farm Land Banks, (2) the War Finance Corporation, and (3) the Federal Intermediate Credit Banks. The creation of these enterprises reflected the congressional view that perceived dysfunction in the credit markets warranted targeted government intervention.

These targeted interventions were important because they revealed a deep-seated belief by Congress that credit policy and monetary policy were different instruments for achieving distinct objectives. This belief can be traced to Carter Glass, senior Democrat from Virginia. Glass was a powerful politician for more than three decades, serving as chairman of the House Committee on Banking and Currency from 1913 to 1918, Secretary of the Treasury during the second term of the Wilson Administration between 1918 and 1920, ranking member of the Senate Committee on Banking and Currency during the 1920s and early 1930s, and, later, chairman of the Senate Appropriations Committee. ${ }^{59}$

Glass spoke frequently about agricultural credit markets, the Federal Reserve, inflation, and the real bills doctrine during debates about the federal credit programs. As the leading congressional framer of the Federal Reserve Act, Glass had an unwavering commitment to the real bills doctrine and to the structure of the Federal Reserve System. For example, Glass reminded the Senate in 1922 that the Federal Reserve Banks were "banks of banks," meaning "they do not loan, can not loan, a dollar to any individual in the United States nor

\footnotetext{
${ }^{56}$ Quoted in Putnam (1916, 770).

${ }^{57}$ Putnam $(1916,771)$. The report omits discussion of the role played by risk in determining borrowers' interest rates.

${ }^{58}$ Saulnier, Halcrow, and Jacoby (1958, 7-23, 28). Radford (2013).

${ }^{59}$ Page (1997)
}

to any concern or corporation in the United States, but only to stockholding banks," and he summarized the great achievement of the Federal Reserve Act thus: "We substituted for a rigid bond-secured circulating medium, unresponsive at any time to the commercial requirements of this great Nation, a perfectly elastic currency, based on the sound, liquid commercial assets of the country, responsive at all times and to the fullest extent to every reasonable demand of legitimate enterprise." ${ }^{\prime 60}$

Political leaders from both parties deferred to Glass' expertise, and his position in Congress allowed him to exercise great influence over any legislation pertaining to banking and credit markets. ${ }^{61}$ In the years following passage of the Federal Reserve Act, Glass strictly adhered to a narrow view of Federal Reserve responsibilities, and his great sway in Congress prevented any significant deviation from the real bills doctrine.

\section{Federal Farm Loan Act of 1916}

The Federal Farm Loan Act of 1916 created the first federally sponsored credit institution: the Federal Land Bank System.

The twelve Federal Land Banks (FLBs) that made up the system provided long-term mortgage credit to farmers and ranchers at low rates of interest. ${ }^{62}$ Capitalized in large part by the federal government, the FLBs were required to maintain a minimum capital stock of $\$ 9$ million in total and were given statutory authority to borrow in the capital markets by issuing partially tax-exempt bonds (on which they were jointly and severally liable), with the total amount outstanding at any time limited to twenty times the amount of their paid-in capital and surplus. ${ }^{63}$ Congress did not make any changes to the Federal Reserve's powers in response to the creation of the

${ }^{60}$ Congressional Record, 67th Congress, 2nd session, p. 1235-6, January 16, 1922.

${ }^{61}$ Committee on Banking and Currency (1922, 375). For example, during 1922 hearings about rural credits, then-Secretary of Commerce Herbert Hoover, when testifying in front of the Senate Committee on Banking and Currency about Federal Reserve discount eligibility provisions, stated "I hesitate to speak in the presence of Senator Glass on these questions, who is so much more master of them."

${ }^{62}$ Federal Farm Loan Act of July 17, 1916, 39 Stat. 360; Putnam $(1916,775)$.

${ }^{63}$ Section 5 of the Federal Farm Loan Act discusses the FLBs' capital, Paragraph 4 of Section 14 provides the maximum bond issue requirements, and Section 21 discusses the liability for the FLBs' bond issues. The Land Banks were to issue shares in $\$ 5$ denominations that could be purchased by the public, with the condition that the Secretary of the Treasury would subscribe any remaining balance if a Federal Land Bank did not meet the statutory minimum. At the end of the Land Banks' first year of operation, their capital stock totaled just short of $\$ 10$ million, of which approximately $\$ 9$ million was subscribed to by the U.S. Treasury (U.S. Treasury Annual Report, 1917, 670). 
Land Banks other than to allow Reserve Banks to purchase FLB bonds (Table 2). ${ }^{64}$ The FLBs could not seek advances from or discount eligible paper with the Reserve Banks; Federal Reserve Banks could not discount member bank loans secured by Land Bank bonds; and Land Bank bonds and member bank loans secured by Land Bank bonds were not eligible collateral for Federal Reserve advances. ${ }^{65}$

Carter Glass' public statements about the Federal Farm Loan Act reflect Congress' unwillingness to alter Federal Reserve powers. Glass lauded the passage of the act, telling the press that with this plan, "the farmers of the United States have a system of credits upon which to conduct their operations," adding that "there is no 'corn tassel' or 'printing press' nonsense about the new law. It is a measure of real substance." 66

\section{War Finance Corporation Act of 1918}

Congress established the War Finance Corporation (WFC) during World War I to lend to financial intermediaries making loans to industries deemed essential to the war effort. ${ }^{67}$ The U.S. Treasury was authorized to subscribe up to $\$ 500$ million in capital, and the WFC could issue debt, with the amount outstanding subject to a leverage limit of six times the WFC's paid-in capital and surplus. ${ }^{68}$ The WFC could not seek advances from or discount eligible paper with the Federal Reserve Banks. ${ }^{69}$ Like the debt of the FLBs, WFC debt was not backed by the U.S. Treasury and could be purchased by

\footnotetext{
${ }^{64}$ Section 27 of the Federal Farm Loan Act.

${ }^{65}$ Hackley $(1973,44,93)$ writes "No change was made in the discounting authority of the Federal Reserve Banks but both the Reserve Banks and member banks of the Federal Reserve System were specifically authorized to buy and sell farm loan bonds issued by the land banks." In 1917, the Federal Reserve Board's general counsel ruled that farm loan bonds were not "bonds of the United States" and were thus ineligible as collateral for advances to member banks. The Board affirmed this ruling in December 1918 (Federal Reserve Bulletin, December 1918, p. 1216).

66 "President Signs Rural Credits Bill," New York Times, July 18, 1916.

${ }^{67}$ War Finance Corporation Act of April 5, 1918, 40 Stat. 506.

${ }^{68}$ Section 2 of the War Finance Corporation Act provides "that the capital stock of the Corporation shall be $\$ 500,000,000$, all of which shall be subscribed by the United States of America." Section 12 provides the leverage limit: "That the Corporation shall be empowered and authorized to issue and have outstanding at any one time its bonds in an amount aggregating not more than six times its paid-in capital ..."

${ }^{69}$ Hackley $(1973,51)$ wrote that the Agricultural Credits Act of 1923 was "the first instance in which the discount facilities of the Federal Reserve Banks were made available to any but member banks of the Federal Reserve System," implying that this privilege was not extended to the WFC in 1918.
}

Federal Reserve Banks. ${ }^{70}$ Unlike FLB debt, however, WFC debt could also be brought into the Federal Reserve System through member bank discounts and advances (Table 2). Member bank loans secured by WFC debt, like those secured by Treasury collateral, could be discounted by Federal Reserve Banks, and WFC debt and member bank loans secured by WFC debt were eligible collateral for Federal Reserve advances. ${ }^{71}$ Moreover, such discounts and advances could be used to back Federal Reserve notes. ${ }^{72}$

The disparate treatment of WFC bonds and FLB bonds in the context of Federal Reserve discounts and advances reflected the wartime exigencies that prompted other significant departures from the real bills doctrine (described in Section 2.1) and the temporary status of the WFC as compared with the FLBs. Glass sought to limit the changes to Federal Reserve discounting and note-issuance powers by insisting that Reserve Bank discounts of member bank loans secured by WFC bonds bear interest at a rate at least 1 percent higher than the discount rate for real bills of a corresponding maturity. ${ }^{73}$ As Glass explained at the time,

[this provision is] the only thing that stands, textually, between the Federal Reserve System and utter wreck. It is the one literal safeguard which should not be abandoned or weakened. I do not believe that the House or the country would desire to see the commercial banking credit system of the country impaired or menaced by

${ }^{70}$ Section 17 of the War Finance Corporation Act states, "That the United States shall not be liable for the payment of any bond or other obligation or the interest thereon issued or incurred by the Corporation, nor shall it incur any liability in respect of any act or omission of the Corporation."

${ }^{71}$ Section 13 of the War Finance Corporation Act states, "That the Federal Reserve Banks shall be authorized ... to discount the direct obligations of member banks secured by such bonds of the corporation and to rediscount eligible paper secured by such bonds and indorsed by a member bank." The advances authority was clarified in Regulation A, 1920 Series (Federal Reserve Bulletin, November 1920, p. 1179).

${ }^{72}$ Committee on Finance $(1918,20)$. The War Finance Corporation Act granted the Federal Reserve Board the power to charge Federal Reserve Banks a fee for any Federal Reserve notes backed by such discounts or advances (Section 13, second paragraph).

${ }^{73}$ Committee on Banking and Currency $(1921,6)$. In 1921, William Harding of the Federal Reserve Board testified that, "That section [of the War Finance Corporation Act] provided that paper secured by War Finance Corporation bonds, where it did not go beyond the time limit provided in Section 13, was eligible and could be rediscounted at rates, I think, 1 per cent above the official discount rate of the Federal Reserve Bank. That provision was put in by those who drafted the bill to meet the objections, I believe, of Mr. Glass, very largely, who was at that time chairman of this committee. . . Mr. Glass insisted on the 1 per cent differential, the idea being that we were at war and that no one knew just how large this issue was going to grow in volume, and that there had better be some protection in the way of differential." 
TABLE 2

Federal Reserve Eligibility Provisions prior to January 1932

\begin{tabular}{|c|c|c|c|c|c|c|}
\hline \multirow[b]{2}{*}{ Instrument } & \multicolumn{3}{|c|}{ Eligibilities } & \multicolumn{3}{|c|}{$\begin{array}{c}\text { Can Collateralize } \\
\text { Federal Reserve Notes If . . }\end{array}$} \\
\hline & For Purchases & For Discounts & $\begin{array}{l}\text { As Collateral on a } \\
\text { Fifteen-Day Advance }\end{array}$ & Purchased & Discounted & $\begin{array}{c}\text { Used to Secure a } \\
\text { Fifteen-Day Advance }\end{array}$ \\
\hline Real bills & Yes $^{\mathrm{a}}$ & Yes $^{\mathrm{a}}$ & Yes $^{\mathrm{b}}$ & $\mathrm{Yes}^{\mathrm{b}}$ & Yes $^{\mathrm{a}}$ & Yes $^{c}$ \\
\hline Treasury debt & $\mathrm{Yes}^{\mathrm{a}}$ & No & Yes $^{\mathrm{b}}$ & No & No & Yes $^{c}$ \\
\hline $\begin{array}{l}\text { Member bank loan secured } \\
\text { by Treasury debt }\end{array}$ & No & Yes $^{\mathrm{a}}$ & Yes $^{\mathrm{b}}$ & No & Yes $^{\mathrm{a}}$ & Yes $^{c}$ \\
\hline FLB debt & Yes $^{\mathrm{d}}$ & No & No & No & No & No \\
\hline $\begin{array}{l}\text { Member bank loan secured } \\
\text { by FLB debt }\end{array}$ & No & No & No & No & No & No \\
\hline WFC debt & $\mathrm{Yes}^{\mathrm{e}}$ & No & Yes $^{\mathrm{f}}$ & No & No & Yes $^{f}$ \\
\hline $\begin{array}{l}\text { Member bank loan secured } \\
\text { by WFC debt }\end{array}$ & No & $\mathrm{Yes}^{\mathrm{e}}$ & Yes $^{f}$ & No & $\mathrm{Yes}^{\mathrm{e} \dagger}$ & Yes $^{f}$ \\
\hline RFC debt ${ }^{\mathrm{h}}$ & No & No & No & No & No & No \\
\hline $\begin{array}{l}\text { Member bank loan secured } \\
\text { by RFC debt }\end{array}$ & No & No & No & No & No & No \\
\hline
\end{tabular}

Notes: FLB is Federal Land Bank. WFC is War Finance Corporation. FICB is Federal Intermediate Credit Bank. RFC is Reconstruction Finance Corporation.

Statutory and Regulatory Authorizations:

${ }^{\text {a }}$ Federal Reserve Act of December 23, 1913

${ }^{\mathrm{b}}$ Act of September 7, 1916

${ }^{\mathrm{c}}$ Act of July 21, 1917

${ }^{\mathrm{d}}$ Federal Farm Loan Act of July 7, 1916

${ }^{\mathrm{e}}$ War Finance Corporation Act of April 5, 1918

${ }^{\mathrm{f}}$ Regulation A (Series of 1920), Federal Reserve Bulletin, November 1920, pp. 1179

g Agricultural Credits Act of March 4, 1923

${ }^{\mathrm{h}}$ Reconstruction Finance Corporation Act of January 22, 1932

* Includes banker's acceptances.

$\dagger 1$ percent penalty rate of interest on Federal Reserve notes issued.

the operations of an emergency system chiefly devised to refund the obligations and finance the business of public-service corporations, railroads, war-supply enterprises, and great concerns that relate themselves to the conduct of the war. ${ }^{74}$

The absence of a penalty rate, Glass warned, "would clutter up the Federal Reserve Banks with unliquid securities, and to that extent impair, if not exhaust, their ability

\footnotetext{
${ }^{74}$ Congressional Record, 65th Congress, 2nd session, p. 3843-4, March 21, 1918.
}

to minister readily to current commerce and industry." Representative Louis T. McFadden of Pennsylvania, a Republican, opposed the bill on the grounds that "if you give the War Finance Corporation the power to issue credit instruments and clothe such instruments with a special privilege which similar instruments do not possess, you will thereby increase the facilities for inflation." 75

Since the WFC mainly financed itself with Treasury equity rather than debt, the provisions related to Federal

${ }^{75}$ McFadden's speech quoted in "Voice Opposition to War Finance Bill," New York Times, March 19, 1918. 
Reserve lending on WFC debt were more important in principle than in practice. The WFC brought only one offering of $\$ 200$ million of one-year bonds in April 1919-after the war had ended. ${ }^{76}$

The contemporary debates concerning the creation of the WFC illuminate views of that period concerning the divergent functions of a government-sponsored enterprise such as the WFC and the Federal Reserve System. Treasury Secretary William McAdoo, in testimony to the House Ways and Means Committee urging creation of the War Finance Corporation, argued that Federal Reserve discount window restrictions influenced bank lending and thereby adversely affected war finance. He contrasted the United States to Europe, arguing that, "in Europe central banks are permitted to grant to banks and bankers loans upon stocks and bonds upon certain well-defined terms."77 McAdoo claimed that the real bills provisions of the Federal Reserve Act had the effect of "forcing the banks to discriminate against loans on ineligible paper, even where such loans were vitally necessary for war purposes, in favor of loans on commercial paper [in other words, real bills]."78 McAdoo reasoned that the Federal Reserve eligibility provisions made member banks less likely to lend on collateral such as stocks or bonds, but he did not at any point suggest altering those provisions. ${ }^{79}$ Rather, he advocated the creation of a new agency to "fill this gap" in the credit markets. ${ }^{80}$

However, certain powerful politicians questioned McAdoo's reasoning. Representative John Nance Garner, Democrat from Texas, asked Paul Warburg, a member of the Federal Reserve Board and framer of the Federal Reserve Act,

\footnotetext{
${ }^{76}$ War Finance Corporation Annual Report $(1919,10)$.

${ }^{77}$ Committee on Ways and Means $(1918,3)$.

${ }^{78}$ Committee on Ways and Means $(1918,4)$.

${ }^{79}$ There were also proposals at the time related to the possible suspension of the country's commitment to a gold standard. Silber (2007) notes that both McAdoo and Congress were reluctant to amend the Federal Reserve Act because they wanted to keep the United States on the gold standard, which they believed ensured its place as a financial superpower.

${ }^{80}$ Committee on Finance $(1918,20)$. In his testimony in the Senate, McAdoo argued that "The Federal Reserve Act does not provide for these and the War Finance Corporation designed as a war emergency to fill this gap. ... The bill contemplates that the War Finance Corporation shall lend money to banks, both National and State, which are making loans to enterprises conducted by persons, firms, or corporations producing materials or supplies, or doing anything else which is necessary for or contributory to the war. If a bank, for instance, should loan money, we will say, to a munitions company and take the company's six months' note with the company's bond as collateral security, that note would not be eligible for rediscount in the Federal Reserve Banks; but the War Finance Corporation in such circumstances could advance to the bank against the note of the munitions company, so secured with that bank's indorsement on it."
}

why he "did not ask Congress to pass a bill amending the Federal Reserve Act ... enabling [him] to do the very things sought to be done in this [War Finance Corporation] bill," later clarifying that "the results sought in this bill could have been accomplished by an amendment to the Federal Reserve Act which would have expired at the end of the war." ${ }^{31}$ Warburg answered that "for the protection of the Federal Reserve System," he would not want to permit "every security which has been issued since this country has existed to be used as collateral for borrowing with the Federal Reserve Banks," adding that "it is a grave responsibility to administer any reserve money."

Similarly, Frederick Gillett of Massachusetts, the House Republican Minority Leader, believed that "the fundamental danger" of the War Finance Corporation bill was that it established a "great corporation which is really a banking corporation." ${ }^{2}$ Since the Federal Reserve System was designed to "meet emergencies," Gillett suggested that problems in war finance could be better addressed with "ordinary banking facilities, improved and assisted by legislation." ${ }^{33}$ Glass immediately countered that "the Federal Reserve Banking system was not intended to meet war emergencies of this description.... It was not intended to meet emergencies in the investment securities system of the country ... and ought not to be perverted to that use. ${ }^{84}$ "The purpose of this bill," Glass concluded, "is to finance the war," a purpose that was unrelated to monetary policy. ${ }^{85}$

\section{Agricultural Credits Act of 1923}

The depression of 1920-21 prompted Congress to temporarily expand the WFC's lending powers to allow intermediate-term loans for agricultural purposes ${ }^{86}$ but persistent credit market dysfunctions soon led to an entirely new network of GSEs in $1923 .{ }^{87}$ Created by the Agricultural Credits Act of 1923, the twelve Federal Intermediate Credit Banks (FICBs) were authorized to discount, for certain financial institutions, farmers' short- and intermediate-term

\footnotetext{
${ }^{81}$ Committee on Ways and Means (1918, 37-38).

${ }^{82}$ Congressional Record, 65th Congress, 2nd session, p. 3728, March 19, 1918.

${ }^{83}$ Congressional Record, 65th Congress, 2nd session, p. 3728, March 19, 1918.

${ }^{84}$ Congressional Record, 65th Congress, 2nd session, p. 3728, March 19, 1918.

${ }^{85}$ Congressional Record, 65th Congress, 2nd session, p. 3752, March 19, 1918.

${ }^{86}$ Agricultural Credits Act of August 24, 1921, 42 Stat. 181.

${ }^{87}$ Hackley $(1973,44)$; Agricultural Credits Act of March 4, 1923, 42 Stat. 1454
} 
notes. ${ }^{88}$ The government-sponsored FICBs did not lend directly to farmers, but rather served as banks of discount to agricultural cooperatives, commercial banks, and other lenders. ${ }^{89}$ The FICBs were capitalized with $\$ 60$ million from the U.S. Treasury and were authorized to issue debt (for which the U.S. government assumed no liability) up to ten times their paid-in capital and surplus. ${ }^{90}$

Federal Reserve Banks were authorized to purchase FICB debt. However, member bank loans secured by FICB debt could not be discounted at Federal Reserve Banks, and FICB debt and member bank loans secured by FICB debt were not eligible collateral for Federal Reserve advances (Table 2). Unlike the Federal Land Banks and the War Finance Corporation, the FICBs were authorized to discount with Federal Reserve Banks any eligible real bills that they had discounted for member banks, ${ }^{91}$ making the FICBs the only institutions other than member banks with access to the Federal Reserve's discount window. ${ }^{92}$

\section{Credit Policy and the Central Bank}

In the years leading up to the Great Contraction, lawmakers-Carter Glass, in particular-were reluctant to broaden the statutory provisions related to what could be discounted or used as collateral for advances at Federal Reserve Banks, even though doing so could have aided their

\footnotetext{
${ }^{88}$ Saulnier, Halcrow, and Jacoby $(1958,175)$.

${ }^{89}$ Hackley $(1973,45)$. In 1933, the FICBs were granted the authority to also lend to production credit associations. (Farm Credit Act of June 16, 1933, 48 Stat. 257.)

${ }^{90}$ Section 203(c) of the Agricultural Credits Act of March 4, 1923, reads: "The United States Government shall assume no liability, direct or indirect, for any debentures or other obligations issued under this section, and all such debentures and other obligations shall contain conspicuous and appropriate language, to be prescribed in form and substance by the Federal Farm Loan Board and approved by the Secretary of Treasury, clearly indicating that no such liability is assumed."

${ }^{91}$ Section 404 of the Agricultural Credits Act of March 4, 1923, amended the Federal Reserve Act by adding Section 13a, which read: "That any Federal Reserve Bank may, subject to regulations and limitations to be prescribed by the Federal Reserve Board, rediscount such notes, drafts, and bills for any Federal Intermediate Credit Bank, except that no Federal Reserve Bank shall rediscount for a Federal Intermediate Credit Bank any such note or obligation which bears the indorsement of a nonmember State bank or trust company which is eligible for membership in the Federal Reserve System, in accordance with section 9 of this Act." The FICBs could not bring for discount at Federal Reserve Banks any bank loans secured by Treasury securities.

${ }^{92}$ Hackley $(1973,51)$ writes, “This was the first instance in which the discount facilities of the Federal Reserve Banks were made available to any but member banks of the Federal Reserve System."
}

goals concerning credit markets. Instead, Congress chose to delegate the responsibility for exercising credit policy to government-sponsored enterprises with well-defined statutory objectives. With few exceptions, Congress did not allow assets other than real bills to be brought for discount or used as collateral for advances, nor did it permit assets other than real bills or gold to back Federal Reserve notes.

Congress' preference for improving the functioning of credit markets through the creation of targeted GSEs rather than the amendment of Federal Reserve powers would continue well into the early years of the Great Contraction, as exemplified by the debates surrounding the creation of the Reconstruction Finance Corporation.

\section{Initial Congressional Responses to the Great Contraction}

\subsection{A Worsening Situation Prompts Two Hoover Proposals}

Just seven months after assuming the presidency, Herbert Hoover faced the beginnings of the worst financial crisis the United States had ever seen. In the year following the stock market crash of October 1929, industrial production, wholesale prices, and personal income fell dramatically, by 26 percent, 14 percent, and 16 percent, respectively. ${ }^{93}$ The declines were followed by internal drains of lawful money, when the American people ran to their banks and withdrew their deposits for currency and gold. The runs strained the banking system and led to temporary suspensions and outright failures. ${ }^{94}$ In November 1930, 256 banks holding $\$ 180$ million of deposits suspended; this number increased in December, when another 352 banks holding $\$ 370$ million of deposits suspended. ${ }^{95}$

${ }^{93}$ Friedman and Schwartz $(1963,306)$.

${ }^{94}$ Calomiris and Mason (2003) examine microeconomic data during the Depression (prior to 1933) and find that the majority of bank failures can be explained by "fundamentals" rather than a "panic." They find that "depositor panic" only became a significant contributor to nationwide distress at the end of 1932. This result questions the Friedman and Schwartz argument that banking distress in 1930 and 1931 reflected depositor panic and illiquidity. This remains a point of contention in the literature.

${ }^{95}$ Friedman and Schwartz $(1963,308-9)$. These numbers are not seasonally adjusted. Calomiris and Mason (2003) discuss the interesting fact that most of the banks that failed during this period were small, as evidenced by the large number of failed banks but small number of total deposits. 
Bank failures worsened after Britain abandoned the gold standard on September 21, 1931. ${ }^{96}$ Foreign depositors, fearing that the United States might do the same, sought to convert their U.S. dollar-denominated assets into gold. ${ }^{97}$ The lethal combination of domestic depositors' demand to convert bank deposits into lawful money and foreign gold outflows put pressure on commercial bank reserves and the Federal Reserve's gold reserves. ${ }^{98}$ The Federal Reserve Bank of New York reacted to the external drain of gold by raising its discount rate by 100 basis points on October 9 and by another 100 basis points a week later. ${ }^{99}$ The contractionary policy staunched gold outflows but prompted an intensified wave of bank failures, with 522 banks, holding $\$ 471$ million of deposits, suspending operations in the month of October. ${ }^{100}$

Congress and President Hoover did not immediately support federal intervention in credit markets to counteract financial market disruptions. However, faced with deteriorating banking conditions in late 1931, Hoover developed a two-pronged approach that, he believed, would prevent further systemic bank failures.

First, as a longer-term solution, Hoover asked Congress to broaden the lending powers of the Federal Reserve. In a speech on October 4,1931, he identified the problem of bank failures and stated that "the obvious method followed by a bank threatened with pressure from its depositors is to meet its obligation either by recourse to its Federal Reserve Bank or its city correspondent, by the sale of securities, or by the disposition of other liquid assets." ${ }^{101}$ However, "the amount of eligible paper held by banks which may be perfectly solvent but which are, nevertheless, threatened, may be totally inadequate to meet immediate emergencies." Recognizing that a liquidity crisis can threaten even a solvent bank, Hoover concluded that a long-term solution to "meet this handicap would be to extend the eligibility provisions of the Federal Reserve Act" for discounts and advances. Unsurprisingly, Hoover had the support of the country's bankers. ${ }^{102}$

\footnotetext{
${ }^{96}$ Friedman and Schwartz $(1963,315)$.

${ }^{97}$ Federal Reserve Bulletin, October 1931, p. 554; Friedman and Schwartz $(1963,316)$.

${ }^{98}$ Eichengreen (1992, 296); Friedman and Schwartz (1963, 316); Meltzer (2003, 345).

${ }^{99}$ Friedman and Schwartz $(1963,317)$

${ }^{100}$ Friedman and Schwartz $(1963,317)$.

${ }^{101}$ Hoover, "Statement on Financial and Economic Problems," October 4, 1931

102 Olson $(1977,26)$.
}

Despite Hoover's urging, the Senate Banking Committee refused to consider expanding Federal Reserve authorities. Senator Glass, then the ranking member of the committee, attacked Hoover's suggestion to broaden Federal Reserve discount eligibility rules, saying "the result of such action would wreck the Federal Reserve System. Congress will never consent to it while I am alive and my health is excellent." ${ }^{103} \mathrm{He}$ argued that member banks held plenty of eligible commercial paper, which showed that "the greater part of the persistent talk for 'broadening the base for eligible paper' is not intended to help legitimate business, which has not been denied ample accommodation by the Federal Reserve Banks." 104 The press questioned Glass' assertion, pointing out that while banks at an aggregate level held more than $\$ 3.5$ billion of assets eligible for Federal Reserve discounts, this number masked the truly negligible amount of eligible paper held by banks in distressed regions. ${ }^{105}$ Regardless, with such strong opposition from Senator Glass, Hoover could not muster enough support in Congress for amending the Federal Reserve Act and was forced to concede the issue. ${ }^{106}$

The second part of Hoover's plan for recovery consisted of a shorter-term solution. To meet the economy's urgent needs, Hoover called for a voluntary private sector initiative aimed at increasing public confidence in the banking system, believing that bolstering trust in the banks would help stimulate capital investment and, eventually, economic recovery. ${ }^{107}$ On October 4, 1931, Hoover met with the nation's largest bankers in a secret meeting at the Washington, D.C., home of Secretary of the Treasury Andrew Mellon. ${ }^{108}$ Hoover urged the bankers to create a

${ }^{103}$ Glass, quoted in "Hoover to Take Up Rail Bond Problem," Baltimore Sun, October 10, 1931.

${ }^{104}$ Glass, quoted in "Glass Sees Hoover Plans Misapplied," Washington Post, October 11, 1931.

105 “Ability to Pay U.S. War Debt Basis," New York Herald Tribune, October 10, 1931. Friedman and Schwartz $(1963,405)$ seem to agree with Glass. They argue that in fact "member banks could have been encouraged to increase their discounts. At all times there was ample eligible paper in the portfolios of member banks." Eichengreen $(1992,297)$ also notes that "few member banks perceived a large number of attractive investment opportunities for using cash obtained from the Fed" and so displayed an "unwillingness to rediscount commercial paper."

106 “Glass Opposes Change in Federal Reserve," New York Times, October 9, 1931.

${ }^{107}$ Hoover, "Statement on Financial and Economic Problems," October 4, 1931. "If . . we could set up one or more central organizations which would furnish rediscount facilities to banks throughout the country on the basis of sound assets not legally eligible for rediscount at the Federal Reserve Bank, we would not only restore liquidity to solvent institutions, but what is even more important, we would at once tend to restore confidence now sadly lacking among all classes of bank depositors in all sections of the country."

${ }^{108}$ Olson $(1977,26)$. 
temporary, privately funded credit pool to lend to troubled banks on the basis of "sound assets" not eligible for discount at the Federal Reserve. ${ }^{109} \mathrm{He}$ hoped that pooling resources across banks would make banks more likely to lend since any potential losses would be shared. The country's bankers were skeptical of Hoover's plan, convinced that a private program would not be large enough, and believed that a federal credit institution similar to the War Finance Corporation was necessary. Nevertheless, they agreed to cooperate on the condition that Hoover ask Congress for federal intervention if the private agency failed. ${ }^{110}$

Two weeks later, the country's strongest banks formed the National Credit Corporation (NCC). The NCC was capitalized with $\$ 500$ million from the participating banks, while its bylaws authorized up to $\$ 1$ billion in debt issuance. ${ }^{111}$ Any bank willing to subscribe capital equal to 2 percent of its time and demand deposits could join the NCC. ${ }^{12}$ Unlike Federal Reserve Banks, the NCC was permitted to lend to nonmember banks on ineligible paper. ${ }^{113}$

Hoover hoped that the NCC could prevent bank failures by providing emergency loans to distressed banks, which would, in turn, increase their commercial loans and bolster business activity. ${ }^{114}$ However, the NCC adopted restrictive collateral requirements and refused to accept any real estate or agricultural paper as collateral for fear of incurring losses. ${ }^{115} \mathrm{~A}$ decrease in the number of bank failures between October and November 1931 made the banking community optimistic that the banking crisis would subside on its own, and the NCC's lending operations were suspended. ${ }^{116}$

\subsection{The Reconstruction Finance Corporation}

In December 1931, bank failures began increasing once again and the seasonally adjusted industrial production index continued to decline. ${ }^{117}$ Hoover was forced to accept the failure of the NCC and to promote the alternative:

\footnotetext{
${ }^{109}$ Hoover $(1952,85)$.

${ }^{110}$ Olson $(1977,24)$

${ }^{111}$ Olson $(1977,27)$.

${ }^{112}$ Olson $(1977,27)$.

113 “Broader Basis of Credit," New York Times, October 7, 1931.

${ }^{114}$ Olson $(1977,27)$.

${ }^{115}$ Olson $(1977,29)$.

${ }^{116}$ Nash $(1959,456)$.

${ }^{117}$ Bernanke $(1983,262)$.
}

direct federal intervention. That month, the president advanced a wide-ranging economic program that included a federal capital injection into the Federal Land Banks and the creation of a Reconstruction Finance Corporation (RFC), modeled after the War Finance Corporation, which would provide direct loans to agricultural credit agencies, financial intermediaries, and railroads. ${ }^{118}$ Additionally, he repeated his request to relax the eligibility requirements of the Federal Reserve Banks.

Senator Frederic Walcott, Republican from Connecticut, and Representative James Strong, Republican from Kansas, introduced the president's RFC bill to Congress. ${ }^{119}$ The RFC would have a capital stock of $\$ 500$ million, all subscribed by the U.S. Treasury, and would be authorized to issue debt backed by the U.S. Treasury, with the amount outstanding limited to three times the RFC's subscribed capital. ${ }^{120}$ Federal Reserve Banks could not lend to the RFC or discount eligible paper brought by the RFC. Federal Reserve Banks were authorized to discount member bank loans secured by RFC debt, to make advances secured by RFC debt to member banks, to use such discounts and advances to back Federal Reserve notes, and to purchase RFC debt. ${ }^{121}$ The bill mandated a penalty rate of 1 percent above the prevailing discount rate for similar maturities.

${ }^{118}$ Hoover, "Annual Message to Congress on the State of the Union," December 8, 1931. "I recommend that an emergency Reconstruction Corporation of the nature of the former War Finance Corporation should be established. ... It should be in position to facilitate exports by American agencies; make advances to agricultural credit agencies where necessary to protect and aid the agricultural industry; to make temporary advances upon proper securities to established industries, railways, and financial institutions which cannot otherwise secure credit, and where such advances will protect the credit structure and stimulate employment."

${ }^{119}$ Olson $(1977,34)$.

${ }^{120}$ S. 1 and H.R. 5060, 72nd Congress (1931). Section 9 of both H.R. 5060 and S.1 stated: "In the event that the corporation shall be unable to pay upon demand, when due, the principal of or interest on notes, debentures, bonds, or other such obligations issued by it, the Secretary of the Treasury shall pay the amount thereof, which is hereby authorized to be appropriated, out of any moneys in the Treasury not otherwise appropriated, and thereupon to the extent of the amounts so paid the Secretary of the Treasury shall succeed to all the rights of the holders of such notes, debentures, bonds, or other obligations."

${ }^{121}$ Section 9 of both H.R. 5060 and S.1 read: "The Federal Reserve Banks shall have the same powers (1) to discount notes, drafts, and bills of exchange secured by obligations issued by the corporation under this Act, (2) to make advances to member banks on their notes secured by such obligations, (3) to use all paper so acquired, and (4) to purchase and sell such obligations, as they have with respect to bonds and/or notes of the United States: Provided, That the rate at which any such discount or advance shall be made by any Federal Reserve Bank shall be one percentum per annum above its discount rate on 90-day commercial paper then in effect." 
Hoover's RFC bill was not well-received by the Senate, garnering criticism from both Democrats and Republicans.

Democrats objected to the discount, advances, purchases, and note-issuance provisions authorizing RFC debt to be brought into the Federal Reserve System. Senator Glass argued that the eligibility provisions could lead to "two billions of dollars of these acquired [RFC] securities in the lap of the Federal Reserve System." ${ }^{122}$ Glass worried that the discount and advances provisions would "practically repeal here that provision of the Federal Reserve which precludes any nonmember bank from using, directly or indirectly, the rediscount privileges of the Federal Reserve System." ${ }^{123}$ Since the RFC would borrow in the capital markets to finance its loans to nonmember banks and trusts, Glass suggested that Federal Reserve purchases, advances, and discounts involving RFC debt would give nonmember banks and trusts indirect access to Federal Reserve credit. Eventually, Glass succeeded in getting the provisions deleted. ${ }^{124}$ In exchange for these protections that would keep the Federal Reserve System from being "invaded" by RFC debt, Glass agreed to a provision authorizing direct purchases of RFC debt by the Treasury. ${ }^{125}$ (The Treasury, in turn, was likely to fund purchases of RFC debt by increasing its own issuance.)

Some Senate Republicans questioned the need for an RFC-type institution altogether. Senator Smith Brookhart, Republican from Iowa and a member of the Committee on Banking and Currency, was skeptical of whether the War Finance Corporation and the Federal Intermediate Credit Banks had alleviated agricultural distress in the 1920s and

\footnotetext{
122 Subcommittee of the Committee on Banking and Currency $(1931,42)$. Under Secretary of the Treasury Ogden Mills defended the provisions to the Senate Banking Committee, saying that they would "make these [RFC] securities more marketable" because the "banks, of course, are interested in any paper that is eligible to a much greater degree than in any paper that is not eligible; and certainly our trouble today is not that there is too much borrowing at the Federal Reserve Banks. My opinion would be that there is too little borrowing, certainly by the banks that should be borrowing."

${ }^{123}$ Subcommittee of the Committee on Banking and Currency (1931, 42-43). However, Section 19 of the Federal Reserve Act did in fact give nonmember banks indirect access to the Fed's discount window by allowing member banks to borrow from the discount window as agents of nonmember banks when given express permission by the Federal Reserve Board.

124 "Glass Sees Death of Discount Clause," New York Times, January 19, 1932.

125 "Glass Sees Death of Discount Clause," New York Times, January 19, 1932, quotes the Senate Banking Committee's Report: “These bonds, while not eligible for rediscount at the Federal Reserve, will be eligible for both purchase and sale at the treasury of the United States." Section 9 of the Reconstruction Finance Corporation Act specified that "The Secretary of Treasury, in his discretion, is authorized to purchase any obligations of the corporation to be issued hereunder. ... Such obligations shall not be eligible for discount or purchase by any Federal Reserve Bank."
}

questioned the value of creating yet another GSE. ${ }^{126}$ Noting that the RFC would primarily lend to banks, Brookhart asked Eugene Meyer, Governor of the Federal Reserve Board, specifically why the "Federal Reserve Banks were not able to take care of this situation?" 127

Governor Meyer defended the Federal Reserve System to Brookhart by arguing that "the Federal Reserve Bank[s] cannot take care of all kinds of situations. The Federal Reserve System was never designed to do so. It is restricted in its activity and necessarily must be, combining the lending function and the currency issuing function." ${ }^{28}$ Elaborating on the limitations of the Federal Reserve's authorities, Meyer said, “There are areas of activity which [the Federal Reserve Banks] do not touch in the member banks, and there is a large area in banking which they do not touch among the nonmember banks." In essence, the Federal Reserve's monetary function limited its role as a credit agency, Meyer argued. Under Secretary of the Treasury Ogden Mills advocated for the RFC bill by arguing that, "As I visualize this corporation, it puts the Government in a position to close almost immediately any gap that might develop through an emergency in our credit structure." ${ }^{129} \mathrm{He}$ emphasized the importance of RFC lending to nonmember banks: "I do not think the corporation should be limited to dealings with members of the [Federal Reserve] system, because it is obviously intended to cover a much broader field." ${ }^{130}$ Generally speaking, Governor Meyer and Under Secretary Mills defended the RFC plan by arguing that the RFC was necessary to provide emergency loans on ineligible paper to member banks, and to provide emergency liquidity to financial institutions outside the Federal Reserve System.

President Hoover signed the RFC Act into law on January 22, 1932. Hoover described his hopes for the new GSE in his official signing statement: "[The RFC Act] brings into being a powerful organization with adequate resources, able to strengthen weaknesses that may develop in our credit, banking, and railway structure, in order to permit business and industry to carry on normal activities free from the fear of unexpected

\footnotetext{
${ }^{126}$ Subcommittee of the Committee on Banking and Currency $(1931,32)$. Senator Brookhart said: "You stated that this bill would increase the price of agricultural products. I would like to have you point out specifically to me how that is going to happen? We had the War Finance Corporation. That did not do it. We had the Intermediate Credit Bank, and that did not do it."

${ }^{127}$ Subcommittee of the Committee on Banking and Currency $(1931,34)$. The position of "Governor of the Federal Reserve Board" is comparable to today's "Chairman of the Board of Governors of the Federal Reserve System." The title of the position was changed by the Banking Act of 1935.

${ }^{128}$ Subcommittee of the Committee on Banking and Currency $(1931,34)$.

${ }^{129}$ Subcommittee of the Committee on Banking and Currency $(1931,40)$.

${ }^{130}$ Subcommittee of the Committee on Banking and Currency $(1931,43)$.
} 
shocks and retarding influences." ${ }^{131}$ In its final form, the act gave the RFC the authority to lend to a broad set of financial intermediaries, including government-sponsored enterprises like the Federal Land Banks and Federal Intermediate Credit Banks, as well as to railroads, on a wide range of collateral. ${ }^{132}$ The final act preserved the capital and debt-issuance provisions of the original House and Senate bills. ${ }^{133}$

The passage of the RFC Act indicates that both Congress and President Hoover subscribed to the view that government credit extensions were crucial for rescuing an imploding economy. Consistent with the legislature's actions over the preceding decade, Congress preserved the essential structure and functions of the Federal Reserve System and the System's adherence to the real bills doctrine. The responsibility for lending to nonmember banks and lending on ineligible collateral was delegated to the RFC, a targeted GSE created specifically for those purposes.

\section{The Decline of the Real Bills Doctrine: The First Glass-Steagall ACt}

Shortly after Congress passed the RFC Act in January 1932, the United States experienced another gold crisis. ${ }^{134} \mathrm{~A}$ shortage of eligible real bills on the Federal Reserve's balance

${ }^{131}$ Hoover, "Statement about Signing the Reconstruction Finance Corporation Act," January 22, 1932.

${ }^{132}$ Reconstruction Finance Corporation Act of January 22, 1932, 47 Stat. 5. The first paragraph of Section 5 of the statute read: "To aid in financing agriculture, commerce, and industry, including facilitating the exportation of agricultural and other products the corporation is authorized and empowered to make loans, upon such terms and conditions not inconsistent with this Act as it may determine, to any bank, savings bank, trust company, building and loan association, insurance company, mortgage loan company, credit union, Federal Land Bank, joint-stock land bank, Federal Intermediate Credit Bank, [or] agricultural credit corporation." The third paragraph of Section 5 authorized the RFC to "make loans to aid in the temporary financing of railroads and railways engaged in interstate commerce, to railroads and railways in process of construction, and to receivers of such railroads and railways" under certain conditions.

${ }^{133}$ Section 9 of the Reconstruction Finance Corporation Act read: "In the event that the corporation shall be unable to pay upon demand, when due, the principal of or interest on notes, debentures, bonds, or other such obligations issued by it, the Secretary of the Treasury shall pay the amount thereof, which is hereby authorized to be appropriated, out of any moneys in the Treasury not otherwise appropriated."

${ }^{134}$ Eichengreen $(1992,296)$ chronicles how Fed officials felt constrained by maintaining gold convertibility and meeting statutory gold reserve requirements and that they feared a global run on the dollar. Meltzer $(2003,355)$ acknowledges the unpredictability of the gold outflow but questions to what extent that unpredictability constrained Federal Reserve policy. This point continues to be actively debated in the literature. sheet forced the Reserve Banks to devote more of their gold to backing Federal Reserve notes. ${ }^{135}$ By February, gold constituted 70 percent of the reserve held against the notes, materially more than the required 40 percent. ${ }^{136}$

The use of gold to back Federal Reserve notes and the consequent reduction of "free gold" was perceived to be a threat to the integrity of the U. S. gold standard. ${ }^{137}$ President Hoover later summarized this fear in his memoirs, writing that "unless we relieved the situation, we should be compelled to refuse gold payments for export, which would be a public admission that the dollar was no longer convertible, and that we were off the gold standard." ${ }^{138}$ On February 9, 1932, Hoover-with the support of Under Secretary of the Treasury Mills (who would assume the role of Secretary of the Treasury three days later), George Harrison (president of the Federal Reserve Bank of New York), and Governor Meyer of the Federal Reserve Board-approached congressional leaders, including Senator Glass, to discuss the gold situation. Glass "retreated from his previous opposition" to amending the Federal Reserve Act, and decided that the best strategy was to "emphasize matters relating to liberalizing the discount privilege and credit expansion proposals" and avoid discussing the "gold situation which might create more alarm both at home and abroad during the interval before the law was passed." ${ }^{139}$ For Carter Glass, it seems that maintaining the gold standard was a top priority, and he was willing to temporarily suspend the real bills doctrine to do so. Glass agreed to introduce a bill that would allow assets beyond real bills and gold to collateralize Federal Reserve notes (but would keep the Federal Reserve Act's

\footnotetext{
${ }^{135}$ Eichengreen $(1992,296)$.
}

${ }^{136}$ Hoover $(1952,116)$.

${ }^{137}$ Meltzer $(2003,355)$ defines free gold as "the amount of gold held by reserve banks that was not required as a reserve against outstanding base money." Hoover $(1952,116)$ explained the gold standard threat: "Ours was a peculiar situation. ... Because of the reduction of deposits in the commercial banks and thus of their ability to make loans, and the slackness in business, 'eligible' commercial bills were insufficiently available for the 60 per cent end of the currency coverage; and gold had to make up the lack. So the gold reserve against the currency had been forced up from 40 to about 70 per cent. The increase in currency from hoarding of a billion dollars also had to be covered by gold reserves, which froze just so much more gold. Under all these pressures only about $\$ 300,000,000$ of gold was left 'free' for further foreign withdrawals. An investigation at this date revealed that foreigners, including the unpredictable French, still had demand deposits in our banks of about $\$ 1,000,000,000$ which they could withdraw in gold at any moment."

${ }^{138}$ Hoover $(1952,116)$.

${ }^{139}$ Hoover $(1952,117)$ 
40 percent gold reserve requirement), freeing up gold so that the Federal Reserve System could meet any foreign demands and preserve the gold standard. ${ }^{140}$

Senator Glass and Representative Henry B. Steagall, chairman of the House Committee on Banking and Currency, introduced the emergency bill to the House and Senate on February 11; it passed on February 27, 1932, as the Glass-Steagall Act. At only three paragraphs, the act was short, but it dramatically altered the Federal Reserve's lending and note-issuance powers.

First and foremost, in passing the act, Congress discarded the fundamental tenet of the real bills doctrine espoused in the Federal Reserve Act-that Federal Reserve notes should be secured by self-liquidating commercial paper-by allowing government securities to collateralize Federal Reserve notes directly. ${ }^{141}$

Additionally, the Glass-Steagall Act added Section 10B to the Federal Reserve Act, giving the Federal Reserve Board temporary emergency authority to allow advances to member banks secured by "satisfactory" collateral at a penalty rate of interest in cases when the borrowing bank had exhausted its eligible assets. ${ }^{142}$ Specifically, the section read:

Until March 3, 1933, and in exceptional and exigent circumstances, and when any member bank, having a capital of not exceeding $\$ 5,000,000$, has no further eligible and acceptable assets available to enable it to obtain adequate credit accommodations through rediscounting at the Federal Reserve Bank or any other method provided by this Act other than that provided by section 10(a), any Federal Reserve Bank, subject in each case to affirmative action by not less than five members of the Federal Reserve Board, may make advances to such member bank on its time or demand promissory notes secured to the satisfaction of such Federal Reserve Bank: Provided, That (1) each such note shall bear interest at a rate not less than 1 percentum per annum higher than the highest discount rate in effect at such Federal Reserve Bank on the date of such note; (2) the Federal Reserve Board may by regulation limit and define the

\footnotetext{
${ }^{140}$ Hoover $(1952,117)$.

${ }^{141}$ Glass-Steagall Act of February 27, 1932, 47 Stat. 56.

${ }^{142}$ Hackley $(1973,103)$.
}

classes of assets which may be accepted as security for advances made under authority of this section; and (3) no note accepted for any such advance shall be eligible as collateral security for Federal Reserve notes. ${ }^{143}$

The provision had the unusual stipulation that $10 \mathrm{~B}$ advances could not be used to back Federal Reserve notes-likely reflecting the real bills-inspired idea that doing so would threaten the value of the currency issued.

Signaling a growing sense of urgency in Congress, the addition of Section 10B marked the first use of the phrase "exigent circumstances" in the Federal Reserve Act. By granting the Federal Reserve Board a power that could be used only in "exceptional and exigent circumstances," Congress broadened the Federal Reserve's vital role as an emergency provider of liquidity during periods of crisis. Given the expansive nature of the new authority, Congress placed restrictions on its use: Section 10B required an affirmative vote by a supermajority of the seven-member Federal Reserve Board, and it expired after one year. ${ }^{144}$

The decline of the real bills doctrine brought by the Glass-Steagall Act of 1932 opened the door for further legislation that expanded the Fed's powers. ${ }^{145}$ Once Congress relaxed the stringent collateral requirements for Federal Reserve advances by adding Section 10B, the main distinction between the lending powers of the Federal Reserve and those of the RFC lay in their legally permissible counterparties. Federal Reserve lending was limited to member banks, while the RFC could lend to a broader set of counterparties that included other financial intermediaries and railroads. In practice, the Reconstruction Finance Corporation was the sole emergency lender for institutions other than member banks.

${ }^{143}$ Section 2 of the Glass-Steagall Act. (emphasis added)

${ }^{144}$ In fact, Glass went to great lengths to ensure that section $10 \mathrm{~B}$ would be a temporary measure; in the original form of the amendment, $10 \mathrm{~B}$ had the phrase "one year from the date of the approval of this act." To make the clause more specific, he replaced that phrase with "until March 3, 1933," believing that the Federal Reserve would return to a real bills-based discount window system after the "emergency" passed (Congressional Record, 72nd Congress, 1st session, p. 4316, 4321-2, February 19, 1932.) On February 3, 1933, Congress extended section 10B emergency lending for another year, from March 3, 1933, to March 3, 1934 (Act of February 3, 1933, 47 Stat. 794.)

145 That said, Glass continued to pursue real bills-inspired legislation that focused on separating the "legitimate needs of trade" from "speculative" lending but did not involve the credit authorities of the Federal Reserve. Calomiris (2010) points to the separation of commercial and investment banking in the Glass-Steagall Act of 1933 and the adoption of Regulation Q, which prohibited banks from paying interest on demand deposits, as examples of Glass' real bills victories; these rules survived until the 1980s. 


\section{SeCtion 13(3)}

\subsection{The Emergency Relief and Construction Act of 1932}

In the spring of 1932, the financial system seemed on the road to recovery. The Federal Reserve had conducted large-scale open market purchases, which gave member banks additional reserves. ${ }^{146}$ Bank failures declined and bank deposits began to increase. ${ }^{147}$

Hoover hoped that the reviving financial system would bring recovery to the real economy. In his signing statement for the Glass-Steagall Act, he called upon banks "with the assurances and facilities now provided" to extend loans to business and industry "in such fashion as to increase employment and aid agriculture." ${ }^{148}$ However, owing to their dramatically weakened capital positions, banks were loath to make more commercial and industrial loans. ${ }^{149}$

Having determined that private bankers were either unable or unwilling to make loans to businesses that needed credit, Hoover decided that the government-created Reconstruction Finance Corporation should perform this essential function by lending directly to the real economy. ${ }^{150}$ Specifically,

Hoover wanted to authorize the RFC to make loans to "public bodies" or "private enterprises" for "income-producing and self-sustaining enterprises which will increase employment," such as toll roads, bridges, and tunnels. To allow the RFC to finance such loans, Hoover proposed increasing the RFC's borrowing limit from $\$ 1.5$ billion to $\$ 3$ billion.

Senate Majority Leader James E. Watson, Republican from Indiana, and Minority Leader Joseph T. Robinson, Democrat from Arkansas, supported Hoover's plan to expand the RFC's lending powers. ${ }^{151}$ Senator Watson ensured the support of Senate Republicans, and Senator Robinson worked with Senator Robert Wagner of New York to draft a compromise plan that was agreeable to both Senate Democrats

\footnotetext{
${ }^{146}$ Friedman and Schwartz $(1963,322-3)$.

${ }^{147}$ Olson $(1977,56)$. The Wall Street Journal attributed this reversal to successful Federal Reserve policies, RFC lending, and the passage of the Glass-Steagall Act (“U.S. Turns Trend in Bank Deposits," April 29, 1932).

${ }^{148}$ Hoover, "Statement on Signing the Federal Reserve Act Amendments," February 27, 1932.

${ }^{149}$ Friedman and Schwartz $(1963,330)$.

${ }^{150}$ Hoover, "Statement on the Economic Recovery Program," May 12, 1932.

151 "Hoover Urges 3-Point Relief Plan of \$1,500,000 to Use as Loans," New York Times, May 13, 1932; "Snags for a Relief Loan," Wall Street Journal, May 13, 1932.
}

and President Hoover. ${ }^{152}$ Observers were optimistic about the efficacy of the compromise; the New York Times reported that "real cooperation has come at last in Washington." ${ }^{53}$ Wagner introduced the compromise plan to the Senate on May 9, 1932. ${ }^{154}$

However, less than two weeks later, Speaker of the House John Nance Garner, a Texas Democrat, took Senate Democrats by surprise by announcing his own plan for unemployment relief. ${ }^{155}$ House Majority Leader Henry Rainey, Democrat from Illinois, formally introduced Garner's plan the following week. ${ }^{156}$ Senate Democratic leaders "did not react enthusiastically to the Garner relief program," according to the Baltimore Sun, but Garner received "the pledge of House Democrats to support the legislation," according to the New York Herald Tribune. ${ }^{157}$

The Garner and Wagner plans were radically different. Garner's plan gave the RFC the far-reaching authority "to make loans ... to any person," which included individuals, trusts or estates, partnerships, corporations (private, quasi-private, or public), associations, or any state or public subdivision, with no limitations on what projects the loans could finance. ${ }^{158}$ In contrast, Wagner's bill limited RFC loans to states and corporations for "self-liquidating" projects-a crucial feature, in Hoover's view, for ensuring repayment. ${ }^{159}$ Hoover attacked Garner's bill, saying that "it is the most gigantic pork barrel ever proposed to the American Congress. It is an unexampled raid on the Public Treasury." "60 Garner's bill would give the RFC unrestricted powers to "make loans indiscriminately," Hoover declared.

Despite Hoover's protests, Rainey introduced a revised version of Garner's bill on June 3, and on June 7 the House passed the bill over the opposition of 172 House Republicans, with a slim majority of 216 to $182 .{ }^{161}$ Once the measure

\footnotetext{
152 "Idle Relief Accord Is Near in Congress," Washington Post, May 14, 1932.

153 "Relief Issue Brings Harmony in Capital," New York Times, May 21, 1932.

${ }^{154}$ S. 4755 was introduced on May 9, 1932, in the 72nd Congress, 1st session, by Senator Wagner and was cosponsored by fellow Democratic senators Joseph Robinson, Key Pittman, Thomas Walsh, and Robert Bulkley.

155 “Compromise Idea Advanced by Garner Plan," Baltimore Sun, May 20, 1932.

${ }^{156}$ Congressional Record, 72nd Congress, 1st session, p. 11479, May 27, 1932.

157 “Compromise Idea Advanced by Garner Plan," Baltimore Sun,

May 20, 1932; "Democrats Aid Garner's Relief Program Today," New York Herald Tribune, May 27, 1932.

${ }^{158}$ H.R. 12353, 72nd Congress (1932).

${ }^{159}$ Hoover (1952, 107-10).

${ }^{160}$ Hoover, Statement on Emergency Relief and Construction Legislation, May 27, 1932.

${ }^{161}$ Congressional Record, 72nd Congress, 1st session, p. 12244, June 7, 1932.
} 
passed the House, it went to the Senate. On June 23, Wagner successfully moved to replace the House-passed Garner proposal with his bill, after which the Wagner bill passed the Senate. ${ }^{162}$ The Conference Committee returned the reconciled Wagner-Garner Emergency Relief Bill to the House and Senate on July 6, 1932. Garner's clause allowing RFC loans "to any person" remained in the final version. ${ }^{163}$

Hoover denounced the reconciled bill: “The fatal difficulty is the Speaker's insistence upon provision that loans should also be made to individuals, private corporations, partnerships, States, and municipalities on any conceivable security and for every purpose. Such an undertaking by the United States Government makes the Reconstruction Finance Corporation the most gigantic banking and pawn broking business in all history." ${ }^{164}$ Despite Hoover's public rejection, the Wagner-Garner bill passed the House of Representatives on July 7 and the Senate on July $9 .{ }^{165}$ All that remained was the president's signature.

\section{Opposition from the Federal Reserve's Charles Hamlin Sets Section 13(3) in Motion}

Another opponent of the Wagner-Garner bill was Charles Hamlin of the Federal Reserve Board. Hamlin was keenly concerned about the extraordinary new lending powers Congress was aiming to give to the RFC, believing that such powers would infringe on the territory of the Federal Reserve System. On Saturday, July 9, the day the Senate passed the Wagner-Garner bill, Hamlin phoned Senator Glass to "express his disapproval of the power granted in the Relief Bill to the Reconstruction Finance Corporation to make loans to individuals." ${ }^{166}$ He further suggested that "if such a power were ... to be given to the Federal Reserve System, he personally would favor it." Hamlin later told the Federal Reserve Board that Senator Glass initially "did not respond favorably to the idea" but quickly reversed his position and requested that Hamlin "draft an appropriate amendment to

\footnotetext{
${ }^{162}$ Congressional Record, 72nd Congress, 1st session, p. 13787, June 23, 1932.

163 “Conference Report to Accompany H.R. 12445," reprinted in Congressional Record, 72nd Congress, 1st session, p. 14780-9, July 7, 1932.

${ }^{164}$ Hoover, "Statement on Emergency Relief and Construction Legislation," July 6, 1932.

${ }^{165}$ Congressional Record, 72nd Congress, 1st session, p. 14820, 14944, July 7 and July 9, 1932.

${ }^{166}$ Federal Reserve Board minutes, July 12, 1932, p. 10.
}

the Federal Reserve Act." ${ }^{167}$ Hamlin complied with Glass' request and, with the "assistance of the Counsel's office" of the Federal Reserve Board, crafted and mailed a "personal" letter to Senator Glass that included a draft amendment to the Federal Reserve Act giving "Federal Reserve Banks, in emergencies, the power to loan directly on eligible paper." ${ }^{68}$ In his letter, Hamlin contended that there were "merchants in the United States today who are unable to obtain credit, although they can give satisfactory collateral. I know that there are large areas where there are no banks left. I therefore, personally, would favor giving this power in emergencies to Federal Reserve Banks." He attached a list of European central banks that had the "power to deal direct [sic] with individuals," and implied that the power to lend broadly on eligible paper belonged to the central bank.

Within a week, between July 9 and July 16, 1932, Carter Glass managed to get Congress to introduce, amend, and pass Hamlin's proposal.

On Monday, July 11, 1932, two momentous events occurred. First, President Hoover announced his veto of the Wagner-Garner Emergency Relief Bill, stating that "this expansion of authority of the Reconstruction Corporation would mean loans against security for any conceivable purpose on any conceivable security to anybody who wants money." 169 Second, Senator Glass introduced Hamlin's amendment to the Federal Reserve Act as an amendment to a small road appropriations bill in the Senate. ${ }^{170}$ That appropriations bill, H.R. 9642, would come to form the basis of the Emergency Relief and Construction Act.

Glass' amendment proposed adding a third paragraph to Section 13 of the Federal Reserve Act:

In unusual and exigent circumstances the Federal Reserve Board, by the affirmative vote of not less than five members, may authorize any Federal Reserve Bank, during such periods as the said board may determine, at rates established, in accordance with the provisions of section 14, subdivision (d), of this act, to discount for any individual or corporation notes, drafts, and bills of exchange of the kinds and maturities made eligible for discount for member banks under

\footnotetext{
${ }^{167}$ Federal Reserve Board minutes, July 12, 1932, p. 10.

${ }^{168}$ Hamlin, letter from Hamlin to Glass, July 9, 1932. Unfortunately, the statutory language suggested by Hamlin has not been preserved in the historical record.

${ }^{169}$ Hoover, "Veto of the Emergency Relief and Construction Bill," July 11, 1932

${ }^{170}$ Congressional Record, 72nd Congress, 1st session, p. 14981, July 11, 1932.
} 
other provisions of this act, when such notes, drafts, and bills of exchange are indorsed and otherwise secured to the satisfaction of the Federal Reserve Bank: Provided, That before discounting any such note, draft, or bill for an individual or corporation the Federal Reserve Bank shall obtain evidence that such individual or corporation is unable to secure adequate credit accommodations from other banking institutions. All such discounts for individuals or corporations shall be subject to such limitations, restrictions, and regulations as the Federal Reserve Board may prescribe. No note, draft, or bill of exchange discounted under the provisions of this paragraph shall be eligible as collateral security for Federal Reserve notes. ${ }^{171}$

The proposed amendment (“Glass' 13(3) amendment”) was similar to Section 10B, which had been added two months earlier by the Glass-Steagall Act. Both were limited to "exigent circumstances," both required an affirmative vote by a supermajority of the Board, and both required that the borrowing institution be unable to obtain credit in the private markets. Furthermore, Glass' 13(3) amendment, like Section 10B, included the real bills-inspired stipulation that the discounted assets not be used to back Federal Reserve currency.

However, Section 10B and Glass' 13(3) amendment differed in four key ways. First, Section 10B referred to Federal Reserve Bank advances, whereas Glass' 13(3) amendment related to Bank discounts. ${ }^{172}$ Second, 10B allowed any collateral deemed "satisfactory" by the Federal Reserve Bank to secure advances, while Glass' 13(3) amendment limited the eligible paper to "the kinds and maturities made eligible for discount under other provisions of this act"-namely, real bills. Third, while 10B advances were limited to member banks, Glass' 13(3) amendment expanded the Federal Reserve's counterparties to include "individuals and

\footnotetext{
171 Congressional Record, 72nd Congress, 1st session, p. 14981, July 11, 1932. (emphasis added)

${ }^{172}$ The legal distinction between discounts and advances is best summarized by Mengle (1993) and Hackley (1973). Mengle (1993, 23) defines discounts as follows: "Discounts involve a borrower selling 'eligible paper,' such as a commercial or agricultural loan made by a bank to one of its customers, to its Federal Reserve Bank. In return, the borrower's reserve account is credited for the discounted value of the paper. Upon repayment, the borrower gets the paper back, and its reserve account is debited for the value of the paper." In contrast, Hackley $(1973,83)$ refers to advances as a "simpler operation. The member bank merely executes its own note ... and pledges [eligible paper] as security. ... If the advance is not repaid at maturity, the Reserve Bank has a direct claim against the member and does not have to resort to the paper pledged as security unless necessary to satisfy that claim."
}

corporations." Fourth, 10B advances required a penalty rate of interest, whereas 13(3) did not. In short, 13(3) restricted Federal Reserve lending to real bills but expanded the universe of borrowers, whereas 10B expanded Federal Reserve lending to new types of collateral but kept the universe limited to member banks.

On Tuesday, July 12, 1932, one day after Glass introduced his 13(3) amendment to H.R. 9642, President Hoover told a delegation of House members that "the Glass proposal was not acceptable to him," according to the Baltimore Sun. ${ }^{173}$ The Washington Post noted the similarities of Glass' amendment allowing broad Federal Reserve lending to "individuals and corporations" and Garner's provision to allow RFC loans "to any persons" in the vetoed Garner-Wagner Bill, conjecturing that "on the whole it is merely a face-saving section for Speaker Garner." 174

The Federal Reserve Board was flabbergasted by this rapid turn of events, since Hamlin had contacted Glass on his own, without having discussed the matter with the Board. In the Board's Tuesday meeting, "all of the members, except Mr. Hamlin, expressed a strong disapproval of the procedure by which the [Federal Reserve] Act might be amended in an important respect without an adequate opportunity for the Board, the Federal Reserve Banks, or the member banks of the system to consider it carefully or to be heard regarding it." ${ }^{175}$ By that time, the amendment had already received the approval of the Senate Banking Committee, and the Board thought the bill might pass the Senate that day. Board member Adolph C. Miller planned to communicate to Hoover and Glass the Federal Reserve Board's "disapproval of the inclusion of such an important amendment to the Federal Reserve Act," especially since the Board "had not been afforded an opportunity for a hearing on the proposal or careful consideration of its merits." 176

The Board's forecast of Senate action was on target, since a slightly revised form of Glass' proposal did indeed pass the Senate on Tuesday, July $12 .{ }^{177}$ Senator Wagner substituted his bill for the "small road appropriations" provisions of H.R. 9642; the new version of H.R. 9642 was mostly similar to the vetoed Garner-Wagner bill except that Glass'

\footnotetext{
173 "Senate Rushes Through New Relief Bill Framed to Meet Views of Hoover," Baltimore Sun, July 13, 1932.

174 "New Relief Measure Is Passed by Senate; Goes to House Today," Washington Post, July 13, 1932.

${ }^{175}$ Federal Reserve Board minutes, July 12, 1932, p. 11.

${ }^{176}$ Federal Reserve Board minutes, July 12, 1932, p. 11.

177 “Senate Rushes Through New Relief Bill Framed to Meet Views of Hoover," Baltimore Sun, July 13, 1932.
} 
13(3) amendment had replaced Garner's proposal allowing RFC loans "to any person." 178 After Wagner added a two-year limitation to Glass' 13(3) amendment, the Senate voted to pass H.R. 9642, titled the "Emergency Relief and Construction Bill." ${ }^{179}$ The president's disapproval of Glass' 13(3) amendment led the press to speculate that it would be eliminated in the House or when the bill went to conference. ${ }^{180}$ No one traced the amendment back to Charles Hamlin.

On Wednesday, July 13, 1932, President Hoover surprised the press by reversing his opposition to Glass' 13(3) amendment. The New York Times reported that Hoover called Glass that morning to state that the administration would not, after all, oppose his proposal to authorize business loans by Federal Reserve Banks. ${ }^{181}$ The historical record is silent as to why Hoover opposed Glass' amendment when it was first introduced and why he switched his stance after just one day. The Baltimore Sun suggested that "the President and Treasury executive [Ogden Mills] did not have a full understanding of the section when they announced yesterday that it would not be acceptable." ${ }^{182}$ Regardless of the reasons for Hoover's change of heart, the president's support for 13(3) was a decisive political achievement for Glass.

The New York Times reported that Governor Meyer of the Federal Reserve Board, after participating in a telephone conference with Glass and Secretary of the Treasury Mills, also guaranteed his support for Glass' 13(3) amendment. ${ }^{183}$ However, the Federal Reserve Board remained sharply divided. ${ }^{184}$ On the morning of Wednesday, July 13, two members of the Board, George R. James and Wayland W. Magee, dissented to the Board's support for Glass' 13(3) amendment, believing that the Board had not considered the views of many who were "vitally interested in all important amendments to the Federal Reserve Act," such as the Federal Reserve Banks. ${ }^{185}$ (Whether James and Magee's Wednesday morning dissention

\footnotetext{
178 Congressional Record, 72nd Congress, 1st session, p. 15098, July 12, 1932.

${ }^{179}$ After Wagner's change, Glass' 13(3) amendment read "For a period of two years, in unusual and exigent circumstances ..." Congressional Record, 72nd Congress, 1st session, p. 15121, 15131, July 12, 1932.

180 "Senate Rushes Through New Relief Bill Framed to Meet Views of Hoover." Baltimore Sun, July 13, 1932; "Relief Bill Voted Quickly by Senate along Hoover Lines," New York Times, July 13, 1932.

181 "Final Relief Action Likely Today, House Having Passed Bill," New York Times, July 14, 1932.

182 “Hoover Relief Likely to Be Law by Night," Baltimore Sun, July 14, 1932.

183 "Final Relief Action Likely Today, House Having Passed Bill," New York Times, July 14, 1932.

${ }^{184}$ Federal Reserve Board minutes, July 13, 1932, noon meeting, p. 3.

${ }^{185}$ Federal Reserve Board minutes, July 13, 1932, noon meeting, p. 4.
}

occurred before or after Meyer assured Glass that he fully supported Glass' plan is unclear.) Meyer, Hamlin, and Adolph C. Miller, the three other members of the Board, "concurred in the disapproval of the procedure" but believed that "the amendment had meritorious aspects and that, properly administered under suitable limitations, it might prove to be a helpful factor in relieving unsatisfactory credit conditions."

The Board decided to focus on fine-tuning the amendment's language during its two meetings on Wednesday, and Meyer and Hamlin coordinated with congressional leaders and administration officials to influence the final wording of the amendment. ${ }^{186}$ Meyer asked congressional officials to eliminate the provision preventing discounted 13(3) assets from backing Federal Reserve currency because he believed it "carried the implication that the paper which might be acquired by Federal Reserve Banks from individuals and corporations would not meet the same standards as paper acquired from member banks under existing provisions of the law."187 Additionally, the Board asked Hamlin to "suggest" to Glass that "the amendment be changed to make it apply to any individual, partnership, association or corporation," broadening the set of permissible counterparties. ${ }^{188}$

Later that day, the House passed the Emergency Relief and Construction Bill without Glass' provision, and the bill went to the Conference Committee. ${ }^{189}$ As a member of that committee, Glass had great influence over the final wording of the bill and consequently had the opportunity to incorporate Meyer and Hamlin's suggested changes to the 13(3) provision. The Conference Committee removed the limitation preventing the paper discounted under 13(3) from backing Federal Reserve notes, as per Meyer's request, and the committee changed the list of counterparties from "individual or corporation" to "individual, partnership, or corporation," in accordance with Hamlin's suggestion. ${ }^{190}$ Additionally,

\footnotetext{
${ }^{186}$ Federal Reserve Board minutes, July 13, 1932, 4:45 p.m. meeting, p. 1.

${ }^{187}$ Federal Reserve Board minutes, July 13, 1932, noon meeting, p. 3.

${ }^{188}$ Federal Reserve Board minutes, July 13, 1932, 4:45 p.m. meeting, p. 1.

189 Congressional Record, 72nd Congress, 1st session, p. 15482-90, July 15,1932

190 The historical record is silent on why the Conference Committee did not also add "association," as Hamlin suggested.
} 
Glass removed the two-year limitation that had been added by Senator Wagner, making the authorization permanent. ${ }^{191}$ The final version provided that:

In unusual and exigent circumstances, the Federal Reserve Board, by the affirmative vote of not less than five members, may authorize any Federal Reserve Bank, during such periods as the said board may determine, at rates established in accordance with the provisions of section 14, subdivision (d), of this Act, to discount for any individual, partnership, or corporation, notes, drafts, and bills of exchange of the kinds and maturities made eligible for discount for member banks under other provisions of this Act when such notes, drafts, and bills of exchange are indorsed and otherwise secured to the satisfaction of the Federal Reserve Bank: Provided, That before discounting any such note, draft, or bill of exchange for an individual or a partnership or corporation the Federal Reserve Bank shall obtain evidence that such individual, partnership, or corporation is unable to secure adequate credit accommodations from other banking institutions. All such discounts for individuals, partnerships, or corporations shall be subject to such limitations, restrictions, and regulations as the Federal Reserve Board may prescribe. (emphasis added)

The House adopted the Conference Committee report on July 15, and the Senate acted on July 16. President Hoover signed the Emergency Relief and Construction Act into law on July $21,1932 .{ }^{192}$

Hamlin, Hoover, and Glass all saw the adoption of 13(3) as a political victory. Hamlin told Glass: "I am more than ever impressed with the necessity and advantage which will be gained by this new power given to the Federal Reserve Banks." ${ }^{193}$ Glass responded that he thought the addition of 13(3) was "in fact, the only sound and orthodox provision of the entire bill. Judiciously administered it will prove both

\footnotetext{
${ }^{191}$ Glass, letter from Glass to Hamlin, July 25, 1932. "Doubtless you have noted that I made the provision permanent. While the President, Mills, and [Under Secretary of the Treasury Arthur A. Ballantine] and even Eugene Meyer were having a nightmare over the provision, Senator Watson and others induced me to make it temporary. This I did with the fixed purpose to make it permanent later. Meanwhile, the various officials named appeared to recover their equilibrium and I changed the bill in conference."

192 Congressional Record, 72nd Congress, 1st session, p. 15492, 15621, July 15-16, 1932.

${ }^{193}$ Hamlin, letter from Hamlin to Glass, July 23, 1932.
}

useful and profitable to the Federal Reserve System and to the business of the country." ${ }^{194}$ Hoover listed the addition of 13(3) as an administration victory in his memoirs. ${ }^{195}$

After the passage of the Emergency Relief and Construction Act, Glass' exclamation from 1922, that Federal Reserve Banks "do not loan, can not loan, a dollar to any individual in the United States nor to any concern or corporation in the United States, but only to stockholding banks," ceased to be true. ${ }^{196}$ With the power to lend directly to individuals, partnerships, and corporations, the Federal Reserve had become more than a "banker's bank."

\subsection{The Usage and Interpretation of 13(3)}

Federal Reserve officials began discussing how to implement 13(3) even before President Hoover signed the Emergency Relief and Construction bill into law. After the bill passed both houses of Congress, the Federal Reserve Board, anticipating that it would become law, asked the Reserve Banks to research the credit situation in their respective districts "in view of the repeated statements which are being made that business is unable to obtain adequate credit accommodation." ${ }^{197}$ Hamlin wrote to Glass, "if it be true, as many bank presidents aver, that all who deserve credit can get it, and are getting it today, then there will be little for the Federal Reserve Banks to do. I believe firmly, however, that this is not the real condition; that there are thousands of would-be borrowers with adequate collateral and good risks, who would be glad to borrow if they could obtain the necessary credit." ${ }^{198}$

On July 22, Governor Meyer sent President Hoover the preliminary results of the Federal Reserve Banks' research on credit conditions in their districts. Hoover was shocked by the number of borrowers who reported being refused for loans, saying that: "this statement is a complete indictment of the banking situation. ... We cannot stand by and see the American people suffering" owing to "the unwillingness of the banks to take advantage of the facilities provided by

\footnotetext{
${ }^{194}$ Glass, letter from Glass to Hamlin, July 25, 1932.

${ }^{195}$ Hoover $(1952,162)$.

${ }^{196}$ Congressional Record, 67th Congress, 2nd session, p. 1235, January 16, 1922.

${ }^{197}$ Federal Reserve Board minutes, July 19, 1932, p. 13.

${ }^{198}$ Hamlin, letter from Hamlin to Glass, July 23, 1932.
} 
the government." 199 He concluded that "an emergency of the character denominated in Section 210 of the 'Emergency Relief and Construction Act of 1932' has now arisen," referring to the "unusual and exigent circumstances" language in Section 13(3), and urged the Federal Reserve Board to act accordingly.

Noting Hoover's assessment, the Board began discussing the requirements that should accompany 13(3). The Board minutes reveal a serious discussion concerning the extent of authority granted by 13(3) that centered on the distinction between discounts and advances. All agreed that 13(3) "clearly authorize[d] the discount for individuals, partnerships or corporations of paper of the kinds now eligible for rediscount for member banks" - namely, real bills. It was "not clear" to the Board, however, if 13(3) also "authorize[d] Federal Reserve Banks to make direct advances to borrowers." ${ }^{200}$ The ambiguity arose because discounts and advances are similar, but nonetheless distinct, loan operations. ${ }^{201}$ Federal Reserve discounts entail the purchase of eligible paper by a Federal Reserve Bank (as discussed in Section 2.1), while advances involve the lending of funds against a pledge of collateral. The Federal Reserve Act limited what member banks could discount to real bills, but, with the addition of Section 10B, did not limit what could collateralize advances to member banks. Thus, if Section 13(3) authorized advances, then there would be no collateral restrictions; if it was limited to discount operations, then only real bills and member bank loans secured by Treasury securities would be eligible. ${ }^{202}$

Federal Reserve Board member Adolph C. Miller suggested that "while the amendment might be so construed by the Board" to allow direct advances, "he thought the better course would be to see what results could be obtained under the first method and, should that prove ineffective, inadequate, or impracticable, the Board would be in a very much better position to adopt the broader construction necessary to give effect to the remedial purposes of the amendment."203 Miller emphasized that "there should be no assumption of authority and responsibilities not clearly conveyed by the amendment unless and until such a course appeared to be the only practicable way of making the law effective." Accordingly, he suggested that the Board restrict 13(3) discounts to "notes, drafts, and bills of exchange which are now eligible for discount for member banks under the provisions of Section 13 or 13(a) of the Federal Reserve Act and Regulation A of the Federal Reserve Board, and which are also secured to the satisfaction of the Federal Reserve Banks." ${ }^{204}$ While the Board rejected Miller's proposed wording, it complied with the spirit of his suggestion, adopting a narrow construction with the idea that it could adopt the broader construction in the future, if necessary. ${ }^{205}$

The Board's rules were promulgated publicly on July 26, 1932, in a letter to each Reserve Bank. The Board authorized "all Federal Reserve Banks, for a period of six months beginning August 1, 1932, to discount eligible

\footnotetext{
${ }^{202}$ Federal Reserve Board minutes, July 26, 1932, p. 7-8.

${ }^{203}$ Federal Reserve Board minutes, July 26, 1932, p. 8-9.
}

${ }^{204}$ Federal Reserve Board minutes, July 26, 1932, p. 8-9. Miller's suggested proposal read: “The Federal Reserve Board, being satisfied that unusual and exigent circumstances exist which justify such action, hereby authorizes all Federal Reserve Banks for a period of six months from the date of this letter to discount for individuals, partnerships, and corporations, with their indorsement, notes, drafts and bills of exchange which are now eligible for discount for member banks under the provisions of Section 13 or 13(a) of the Federal Reserve Act and Regulation A of the Federal Reserve Board, and which are also secured to the satisfaction of the Federal Reserve Banks."

${ }^{205}$ Federal Reserve Board minutes, July 26, 1932, p. 8-10. "A discussion followed during which the other members of the Board expressed themselves as favoring the adoption at this time of the broader construction of the amendment set forth in Section III of the proposed circular as submitted, and the substitute submitted by Mr. Miller was not adopted." However, the final circular quoted on p. 9-10 of the Board's minutes states: "When so authorized, a Federal Reserve Bank may discount for individuals, partnerships, or corporations only notes, drafts, and bills of exchange of the kinds and maturities made eligible for discount for member banks, under other provisions (Section 13 and 13a) of the Federal Reserve Act. (Such paper must, therefore, comply with the applicable requirements of Regulation A of the Federal Reserve Board)." (emphasis added) 
notes, drafts, and bills of exchange for individuals, partnerships, and corporations, subject to the provisions of the law, the Board's regulations, and this circular." ${ }^{206}$ In accordance with Miller's suggestion, only "notes, drafts, and bills of exchange of the kinds and maturities made eligible for discount for member banks under other provisions (Section 13 and 13a) of the Federal Reserve Act," namely real bills and member bank loans secured by Treasury securities, could be discounted under 13(3).

\section{The Exclusion of State Nonmember Banks and Trusts}

The Federal Reserve Board took the crucial step of determining that "the term 'corporations' does not include banks," meaning that 13(3) did not allow discounts for nonmember banks. ${ }^{207}$ In other words, the Federal Reserve Board did not believe that 13(3) authorized Federal Reserve lending to financial intermediaries outside the Federal Reserve System. The Board would continue to affirm this narrow interpretation, even under significant pressure from Congress and the executive branch.

The final cataclysm of the Great Contraction came in February 1933 when a new wave of bank failures commenced in the United States. ${ }^{208}$ Subsequently, every state, starting with Michigan on February 14, 1933, declared a state bank holiday owing to increasing numbers of bank suspensions. ${ }^{209}$ Finally, on Sunday, March 5, 1933, newly elected President Franklin Delano Roosevelt declared a four-day nationwide bank holiday. ${ }^{210}$ On March 8, Roosevelt held a conference with senior congressional leaders of both parties and proposed an emergency relief measure, which

\footnotetext{
${ }^{206}$ Federal Reserve Bank of New York Circular No. 1124, August 1, 1932, reprinted in Federal Reserve Bulletin, August 1932, p. 518.

${ }^{207}$ Federal Reserve Bank of New York Circular No. 1124.

${ }^{208}$ Federal Reserve Bulletin, March 1933, p. 144.

${ }^{209}$ Silber $(2009,22)$ notes that every state either adopted a de jure bank holiday or placed restrictions on depositor withdrawals that had the same effect as a bank holiday.

${ }^{210}$ Silber $(2009,19)$.
}

he asked to be passed verbatim. ${ }^{211}$ The leadership promised to enact Roosevelt's legislation the next day. There was some dissension, but the leaders kept their word. ${ }^{212}$

The Emergency Banking Act of March 9, 1933, included two sections that broadened the lending powers of the Federal Reserve System. The first change amended Section $10 \mathrm{~B}$ by removing the need for an affirmative vote by a supermajority of the Board and by allowing 10B loans to back Federal Reserve notes, further eroding the real bills doctrine. ${ }^{213}$

The second change added Section 13(13) authorizing Federal Reserve advances to "individuals, partnerships, or corporations" that were secured by "obligations of the United States." Specifically, 13(13) stated:

Subject to such limitations, restrictions and regulations as the Federal Reserve Board may prescribe, any Federal Reserve Bank may make advances to any individual, partnership, or corporation on the promissory notes of such individual, partnership, or corporation secured by direct obligations of the United States. Such advances shall be made for periods not exceeding 90 days and shall bear interest at rates fixed from time to time by the Federal Reserve Bank, subject to the review and determination of the Federal Reserve Board. ${ }^{214}$

The language of section 13(13) differed from that of 13(3) in three main ways. First, 13(13) was an advances power, not a discount power. Second, neither a declaration of "unusual or exigent circumstances" nor an affirmative vote by a supermajority of the Board was required. Third, the class of acceptable collateral was limited to Treasury securities.

\footnotetext{
${ }^{211}$ Congressional Record, 73rd Congress, 1st session, p. 58, March 9, 1933. Carter Glass told the Senate: "At the White House last night we had assembled there the leading representatives of both political parties in both Houses of Congress. With one voice they all agreed, almost if not quite without qualification, in saying that they would unite to enact this legislation before midnight tonight, and that if there might be discovered in it any defects, they should be remedied later."

${ }^{212}$ Senator Huey Long, Democrat from Louisiana, strongly advocated for an amendment to the emergency legislation proposed by President Roosevelt that would have allowed "any state bank" to "be declared" by the President of the United States "a member of the Federal Reserve System" upon "such terms and conditions as the President of the United States may see fit to prescribe." Eventually, the Senate rejected Long's provision and passed the bill, unchanged, as the Emergency Banking Act of March 9, 1933 (Congressional Record, 73rd Congress, 1st session, p. 52, 59-60, March 9, 1933).

${ }^{213}$ Emergency Banking Act of March 9, 1933, 48 Stat. 7. Section 402 of the statute amended Section 10B of the Federal Reserve Act.

${ }^{214}$ Section 403 of the Emergency Banking Act amended the Federal Reserve Act by adding Section 13(13).
} 
Even though both Section 13(3) and Section 13(13) concerned lending to "individuals, partnerships, and corporations," the Federal Reserve Board interpreted the two sections differently. The Board decided that the phrase "individuals, partnerships, and corporations" in Section 13(13) included nonmember banks and trusts, even though it had earlier decided that the phrase did not include those entities for 13(3). ${ }^{215}$

This was no oversight. Roosevelt's personal secretary, Marvin H. McIntyre, asked the Board to reconsider its initial interpretation of Section 13(3) "to include within its operation nonmember state banks under the terms 'corporation." ${ }^{216}$ The Board, "after discussion of the history of the legislation and its apparent intent," reached the conclusion that it "would not be justified in reversing its ruling on this question." 217

Congress, too, noticed the Federal Reserve Board's narrow interpretation of 13(3). On March 14, 1933, Senator Robinson, Democrat of Arkansas, proposed an amendment to the Emergency Banking Act that would grant, for one year, nonmember state banks and trusts direct access to the Federal Reserve's discount window on the same terms provided by Section 10B for member banks. ${ }^{218}$ When the Federal Reserve Board met that day, members expressed great concern about Robinson's amendment, their chief objection being that the legislation was "unnecessary because the Reconstruction Finance Corporation has ample authority to make advances to all kinds of banking institutions including nonmember State banks as well as State member banks and national banks." ${ }^{219}$ In addition to believing that the amendment was unnecessary, the Board felt it was "unfair to the member banks of the Federal Reserve System, who were the sole owners of the Federal Reserve Banks and had contributed not only the entire capital but the bulk of the resources of the System, to use the resources of the Federal Reserve Banks for loans to nonmember State banks which had

\footnotetext{
${ }^{215}$ Federal Reserve Board minutes, March 11, 1933, p. 6-7. "Attention was then called to the fact that [in] the last paragraph of section 13 of the Federal Reserve Act, as amended by the act of March 9, 1933 . . it would appear that Congress intended that the term 'any individual, partnership, or corporation' should include banking institutions; ... After discussion, the Secretary was requested to advise the Federal Reserve Banks by telegraph that the Board considers that the term 'any individual, partnership, or corporation' as used in the last paragraph of Section 13 of the Federal Reserve Act, as amended by the act of March 9, 1933, includes banking institutions, regardless of whether they are members of the Federal Reserve System or nonmembers."

${ }^{216}$ Federal Reserve Board minutes, March 15, 1933, p. 1.

${ }^{217}$ Federal Reserve Board minutes, March 15, 1933, p. 1.

${ }^{218}$ S. 320, 73rd Congress (1933), printed in Congressional Record,

73rd Congress, 1st session, p. 333, March 14, 1933.

${ }^{219}$ Federal Reserve Board minutes, March 14, 1933, p. 11.
}

contributed nothing to the maintenance of the system but, in fact, had competed with it."220 Governor Meyer expressed the Board's view in a strongly worded letter to Senator Glass, saying that the Federal Reserve Board was of the "unanimous" opinion that the Robinson bill "would be highly inadvisable and prejudicial to the best interests of the Federal Reserve System and to the financial structure of the nation." ${ }^{221}$ In Meyer's view, emergency lending to a group of institutions that had declined to be part of the Federal Reserve System was the responsibility of the Reconstruction Finance Corporation.

The Board's objections were so strong that Meyer and Board Secretary Chester Morrill accompanied Secretary of the Treasury William Woodin and Senator Glass to the White House to inform Roosevelt about their views of the bill. ${ }^{222}$ At that meeting, "the President offered a number of suggestions as to safeguards which might be introduced into the bill," including a provision emphasizing that "the making of loans should be discretionary with the Federal Reserve Banks."223

The Board met again at 9:30 that evening to discuss Roosevelt's proposed amendments to the Robinson bill. Shortly after the meeting began, Senator Glass called the Board to express his fear that the bill "as passed by the Senate and to which he was opposed might be sent over to the House and that it might pass in its present form." He said "he would like to have in the morning a draft of the bill modified in accordance with the suggestions which had been made at the White House, and he would also like to have copies of the modifications, so that he could give them to Congressman Steagall."224 The Board obliged, and so a revised version of Robinson's bill, incorporating suggestions from President Roosevelt and the Federal Reserve Board, passed

\footnotetext{
${ }^{220}$ Federal Reserve Board minutes, March 14, 1933, p. 11-12.

${ }^{221}$ Meyer, letter from Meyer to Glass, March 14, 1933.

${ }^{222}$ Federal Reserve Board minutes, March 14, 1933, p. 13. "Governor Meyer reported that in accordance with the understanding with the other members of the Board at their meeting in the Governor's office this afternoon, Dr. Miller and he had participated in a conference at the White House regarding the Robinson bill, S. 320, and that among the others present were also Secretary Woodin, Senator Glass, and Mr. Morrill. The members of the Board were informed that during the discussion at the White House Senator Glass indicated that by unanimous consent, although the bill had passed the Senate, its transmission to the House had been withheld, pending the introduction of a motion to reconsider. It was also stated that the President was informed as to objections which had been expressed by members of the Board to such legislation from the standpoint of the welfare of the Federal Reserve System."

${ }^{223}$ Federal Reserve Board minutes, March 14, 1933, p. 13-14.

${ }^{224}$ Federal Reserve Board minutes, March 17, 1933, p. 17.
} 
the House as H.R. 3757 on March 20, 1933. ${ }^{225}$ The bill was signed into law, with minor modifications, by President Roosevelt on March $24 .{ }^{226}$ As a result, nonmember banks and trusts gained direct access to Federal Reserve credit for a period of one year.

\section{Lender of Last Resort}

The debates concerning the Robinson amendment reveal that Congress disagreed with the Federal Reserve Board about advances to nonmember state banks and trusts. The Federal Reserve Board did not want the additional powers provided by the Robinson bill to lend to nonmember commercial banks on a wide class of collateral. In the Board's view, the appropriate lender for nonmember banks was the Reconstruction Finance Corporation, the institution created by Congress to provide targeted assistance to the financial system. ${ }^{227}$

Additionally, the Board's exclusion of nonmember banks in its interpretation of "corporations" under 13(3) implies that it did not view 13(3) as a lender-of-last-resort authority. What constitutes a lender of last resort is highly debatable, but most definitions emphasize that a lender of last resort aims to prevent banking panics and financial collapse. ${ }^{228}$ Under the strictest definition, a lender of last resort "lends to protect bank-created money stock from contraction in the face of bank runs" by "expanding the stock of [central bank] money to offset falls in velocity." ${ }^{229}$ Using this definition, a lender of last resort, by having the unique authority to create high-powered money, can utilize the force of its balance

\footnotetext{
225 Congressional Record, 73rd Congress, 1st session, p. 640, March 20, 1933.
}

${ }^{226}$ Act of March 24, 1933, 48 Stat. 20; Congressional Record, 73rd Congress, 1st session, p. 789, 849, March 22, March 23, 1933. On March 22, the Senate debated, amended, and passed H.R. 3757. The House concurred in the Senate amendments and agreed to the bill on March 23, 1933.

${ }^{227}$ Interestingly, Fettig (2002) recounts a later debate in Congress about whether the authority to make working capital loans to banks should be endowed to the RFC or to the Fed.

${ }^{228}$ Baxter and Sommer $(1999,209)$ write, "Although one can only be grateful that the LOLR ["lender of last resort"] function is not embalmed in law, the imprecision of the concept is chastening. Everybody agrees that the LOLR function has something to do with liquidity and financial crises. Beyond this point, all is controversy."

${ }^{229}$ Humphrey (2010, 334). Interestingly, Calomiris (2013) reviews studies that examined the limits of collateralized lending for stemming bank runs. Because secured lending to banks could subordinate depositors in bankruptcy, there were times when emergency lending had the counterproductive effect of encouraging more runs. In 1933, Congress responded to the perceived failure of emergency lending by expanding the RFC's powers to allow it to purchase preferred stock in banks and other firms. According to some studies that compared RFC loans to RFC purchases of preferred stock, RFC loans actually raised the probability of a bank failure, while preferred stock assistance reduced the probability of failure. sheet by increasing its liabilities, thereby maintaining the efficacy of the payments system and offsetting a contraction of high-powered money. ${ }^{230}$ Looser definitions state that a lender of last resort can lend even when problems "arise outside the banking system," in which case "the main role of the discount window is in defusing disruptive liquidity crises that occur in particular nonbank financial markets." 231

Section 13(3) loans, being funded with high-powered money rather than, for example, borrowings from the Treasury, could be used to offset contractions in the monetary base. However, the intent of the section decidedly concerned credit conditions in the real economy: Borrowers needing to finance the production and distribution of goods who failed to receive adequate accommodation from commercial banks could seek loans from the Federal Reserve System. In this manner, Section 13(3) established the Federal Reserve as a lender to commercial enterprises. Governor Meyer's statement from 1932 summarizes it in this way: "The administration of the [13(3)] amendment involves a new kind of banking, so far as Federal Reserve Banks are concerned, with which some of the Federal Reserve officials have not had a great deal of experience, and ... to take care of the business which may come to them as a result of the amendment, the banks should, if necessary, add to their forces men experienced in granting commercial bank loans." 232

In 1932, Federal Reserve Banks made a total of $\$ 700,000$ of 13(3) loans. ${ }^{233}$ The Federal Reserve Board renewed the 13(3) authority every six months until July 1936, at which point the Federal Reserve System had made a cumulative total of 123 loans under the authority, aggregating to $\$ 1.5$ million. ${ }^{234}$ The largest loan of $\$ 300,000$ was made to a typewriter manufacturing company; another for $\$ 250,000$ was extended to a vegetable grower. ${ }^{235}$

It is not obvious why Federal Reserve lending under Section 13(3) was so limited in the 1930s. Mehra (2010) suggests three possible causes: (1) stringent Federal Reserve rules on which type of paper could be brought for discount,

\footnotetext{
${ }^{230}$ Schwartz $(1999,2)$ writes, "A financial panic occurs in the money market. It can be quickly ended by a LOLR. . . . A domestic LOLR can create high-powered money without limit."

${ }^{231}$ Calomiris $(1994,32)$.

${ }^{232}$ Federal Reserve Board minutes, July 15, 1932, p. 2.

${ }^{233}$ These data are from Table 88, "Bills Discounted by Class of Paper," in Banking and Monetary Statistics published by the Board of Governors of the Federal Reserve System (1943, 340).

${ }^{234}$ Hackley $(1973,130)$.

${ }^{235}$ Baxter (2009); Hackley $(1973,83)$ identifies “300,000” as the largest sum lent.
} 
(2) limited demand because of more attractive lending terms from the RFC, and (3) subsequent congressional legislation that obviated the need for 13(3) discounts by endowing the Fed with other, more potent tools, namely the power to make "working capital loans" to business. ${ }^{236}$ Perhaps further research will shed light on these claims.

\section{Conclusion}

The addition of Section 13(3) to the Federal Reserve Act in 1932 was preceded by a number of acts that expanded the government's presence in credit markets. The Federal Farm Loan Act of 1916, the War Finance Corporation Act of 1918, and the Agricultural Credits Act of 1923 had all delegated the responsibility for mitigating credit market dysfunctions to new, congressionally created GSEs. The Federal Reserve was deemed a purely monetary institution, its role determined by its ability to create high-powered money. The real bills doctrine was one of the two pillars upon which the Federal Reserve System was built (the other being the gold standard). With gold and discounts of real bills expected to make up the bulk of Federal Reserve assets, the framers of the Federal Reserve Act aimed to furnish an elastic monetary base that could expand and contract with the requirements of trade.

The crisis of the Great Contraction led Congress and the Federal Reserve System to reevaluate the real bills doctrine and their belief that monetary authorities should not exercise discretionary credit policy. The decline of the real bills doctrine began in February 1932 when Congress passed legislation allowing Federal Reserve currency to be backed by government securities. In the same legislation, Congress added Section 10B to the Federal Reserve Act, which permitted advances to member banks on any collateral, blurring the line between monetary policy and credit policy. In July 1932, Congress added Section 13(3) to the act, transforming the Federal Reserve System into a credit institution that could lend directly to the real economy in emergencies. However, despite these sweeping congressional changes, the Federal

\footnotetext{
${ }^{236}$ Section 13(b) was added to the Federal Reserve Act in the Industrial Advances Act of June 19, 1934. It authorized Federal Reserve Banks to "make loans to, or purchase obligations of" an "established industrial or commercial business" for "the purpose of providing it with working capital" when such business was otherwise unable to obtain funds from private markets. The authority was limited to "exceptional circumstances." Section 13(b) was utilized fairly extensively by the Federal Reserve System between 1934 and 1956 but was later repealed by the Small Business Investment Act of August 21, 1958.
}

Reserve Board continued to resist lending to nonmember banks and trusts. In the Board's view, the appropriate emergency lender for those institutions was the Reconstruction Finance Corporation.

In the years and decades following the Great Contraction, Congress continued to modify Federal Reserve lending and note-issuance authorities to reflect evolving economic conditions, steadily broadening both authorities in ways that erased the distinction between member and nonmember banks, and between banks and nonbank financial intermediaries (shadow banks).

In 1935, Congress made Section 10B permanent and removed both the condition of emergency circumstances and the clause requiring member banks to have exhausted all private-sector credit options. ${ }^{237}$ With these changes, Section 10B allowed Federal Reserve Banks to make advances to member banks on any collateral.

In 1966, when it appeared that nonmember depository institutions were experiencing difficulties, the Board of Governors departed from the Depression-era interpretation of Section 13(3) by invoking the authority to allow emergency loans to nonmember depository institutions for a period of two months. ${ }^{238}$ The Board affirmed this interpretation on Christmas Eve of 1969, when it again authorized 13(3) discounts for nonmember depository institutions. ${ }^{239}$ Finally, Congress acted in 1980 by passing the Monetary Control Act, which opened the Federal Reserve's discount window to any depository institution, allowing such institutions to borrow on the same terms as member banks. ${ }^{240}$ By erasing the distinction between member and nonmember banks, the Federal Reserve Board and Congress confirmed that the central bank was to be a lender of last resort for all banks.

Following the October 1987 stock market crash, Congress made a subtle but crucial change to $13(3){ }^{241}$ It required that paper brought for discount need only be "indorsed or otherwise secured to the satisfaction of the Federal Reserve Bank,"

\footnotetext{
${ }^{237}$ Banking Act of August 23, 1935, 49 Stat. 684. Section 204 of the statute amended Section $10 \mathrm{~B}$ of the Federal Reserve Act.

${ }^{238}$ Board of Governors of the Federal Reserve System, 1966 Annual Report, p. 92. "Your bank is authorized, in accordance with the third paragraph of Section 13 of the Federal Reserve Act, in unusual and exigent circumstances to discount for mutual savings banks and other depositorytype institutions paper of the kinds described in that paragraph, subject, however, to the limitations therein contained and in accordance with, and subject to, further limitations now specified by the Board."

${ }^{239}$ Board of Governors of the Federal Reserve System, 1969 Annual Report, p. 92.

${ }^{240}$ Monetary Control Act of March 31, 1980, 94 Stat. 132. The act also removed the penalty rate of interest from Section 10B.

241 "Limits on Fed's Discount Lending Prompts Fears," American Banker, December 31, 1991.
} 
deleting the requirement that the paper be "of the kinds and maturities made eligible for discount for member banks under other provisions of this Act." ${ }^{242}$ The effect of this change was to widen the class of eligible paper for 13(3) discounts beyond real bills and member bank loans secured by Treasury securities. ${ }^{243}$ Senator Chris Dodd, Democrat from Connecticut, testified on this amendment:

"It also includes a provision I offered to give the Federal Reserve greater flexibility to respond in instances in which the overall financial system threatens to collapse. My provision allows the Fed more power to provide liquidity, by enabling it to make fully secured loans to securities firms in instances similar to the 1987 stock market crash." ${ }^{244}$

\footnotetext{
${ }^{242}$ Federal Deposit Insurance Corporation Improvement Act (FDICIA) of December 19, 1991, 105 Stat. 2386. The statute amended Section 13(3) of the Federal Reserve Act to read: "In unusual and exigent circumstances, the Board of Governors of the Federal Reserve System, by the affirmative vote of not less than five members, may authorize any Federal Reserve Bank, during such periods as the said board may determine, at rates established in accordance with the provisions of Section 14, subdivision (d), of this Act, to discount for any individual, partnership, or corporation, notes, drafts, and bills of exchange when such notes, drafts, and bills of exchange are indorsed or otherwise secured to the satisfaction of the Federal Reserve Bank: Provided, That before discounting any such note, draft, or bill of exchange for an individual or a partnership or corporation the Federal Reserve Bank shall obtain evidence that such individual, partnership, or corporation is unable to secure adequate credit accommodations from other banking institutions. All such discounts for individuals, partnerships, or corporations shall be subject to such limitations, restrictions, and regulations as the Board of Governors of the Federal Reserve System may prescribe."

${ }^{243}$ Bowden (1992).

244 Congressional Record, 101st Congress, 1st session, p. S18619, November 27, 1991. (emphasis added)
}

This "technical change" to 13(3) would authorize emergency lending to securities firms, such as broker-dealers, when the financial system was at the brink of collapse, as long as such loans were "secured to the satisfaction" of the Federal Reserve Bank. ${ }^{245}$

Finally, in 2003, Congress authorized any Federal Reserve asset to back Federal Reserve note issuance. ${ }^{246}$

In the spring of 2008, Sections $10 \mathrm{~B}$ and 13(3) formed the statutory basis for the Federal Reserve's lender-of-last-resort powers for member banks, nonmember banks, broker-dealer firms, commercial paper issuers, and money market mutual fund $\mathrm{s}^{247}$ as the Fed moved to bolster a financial system that had arrived at the brink.

\footnotetext{
${ }^{245}$ Clouse $(1994,975)$ writes: "The bulk of the provisions in FDICIA pertaining to the discount window are contained in section 142, but section 473 effects a technical change in the emergency lending powers of the Federal Reserve under section 13(3) of the Federal Reserve Act. Section 473 removes a restriction on the "kinds and maturities" of notes, drafts, and bills of exchange that can be discounted for individuals, partnerships, and corporations under the authority of section 13(3). In those extremely unlikely circumstances in which section 13(3) lending authority might be invoked, this change provides greater flexibility to the Federal Reserve in managing a financial crisis."

${ }^{246}$ Check Clearing for the 21st Century Act of October 28, 2003, 117 Stat. 1177.

${ }^{247}$ Baxter and Sommer $(1999,221)$.
} 


\section{REFERENCES}

Baxter, T. C. 2009. "The Legal Position of the Central Bank: The Case of the Federal Reserve Bank of New York." Remarks given at the London School of Economics on January 19.

Baxter, T. C., and J. H. Sommer. 1999. "Lender-of-Last-Resort Issues-Past, Present, and Future." Current Developments in Monetary and Financial Law. Washington, D.C.: International Monetary Fund.

Bernanke, B. 1983. "Nonmonetary Effects of the Financial Crisis in the Propagation of the Great Depression." American Economic REview 73, no. 3 (June): 257-76.

Board of Governors of the Federal Reserve System. 1943. BANKING and Monetary Statistics. Washington, D.C.

_ 2008. "Report Pursuant to Section 129 of the Emergency Economic Stabilization Act of 2008: Authorization to Provide Residual Financing to Citigroup, Inc. for a Designated Asset Pool." http://www.federalreserve.gov/monetarypolicy/ files/129citigroup.pdf.

_ 2009. "Report Pursuant to Section 129 of the Emergency Economic Stabilization Act of 2008: Authorization to Provide Residual Financing to Bank of America Corporation Relating to a Designated Asset Pool." http://www.federalreserve.gov/ monetarypolicy/files/129bofa.pdf.

—. 2014. "Credit and Liquidity Programs and the Balance Sheet." Last updated on December 9, 2014, accessed May 15, 2015. http://www .federalreserve.gov/monetarypolicy/bst_lendingprimary.htm.

_ 2014. "Bear Stearns, JPMorgan Chase, and Maiden Lane LLC." Last updated on December 9, 2014, accessed May 15, 2015. http:// www.federalreserve.gov/newsevents/reform_bearstearns.htm.

_ 2014. "Primary Dealer Credit Facility (PDCF)." Last updated on December 9, 2014, accessed on May 14, 2015. http://www .federalreserve.gov/newsevents/reform_pdcf.htm.

—. Various Dates. ANNUAL REPORT. Washington, D.C.

_. Various Dates. Federal Reserve Board minutes. Unpublished. Washington, D.C., Library.
—. Various Dates. Federal Reserve Bulletin. Washington, D.C.

— Various Dates. Press releases. Washington, D.C. https://www .federalreserve.gov/newsevents/pressreleases.htm.

Bowden, W. P., Jr. 1992. The Federal Deposit Insurance CorporAtion Improvement ACt OF 1991. W. P. Bowden, Jr., et al., eds. Englewood Cliffs, N.J.: Prentice Hall Law and Business.

Bruner, R. F., and S. D. Carr. 2007. The Panic of 1907: Lessons Learned from the Market's Perfect Storm. Hoboken, N.J.: John Wiley and Sons.

Calomiris, C. W. 1994. "Is the Discount Window Necessary? A Penn Central Perspective." Federal Reserve Bank of St. Louis Review 76, no. 3 (May/June): 31-56.

_ 2010. "The Political Lessons of Depression-Era Banking Reform.” Oxford Review of Economic Policy 26, no. 3: 540-60.

_ 2013. "Volatile Times and Persistent Conceptual Errors: U.S. Monetary Policy, 1914-1951." In M. Bordo and W. Roberds, eds., The Origins, History, and Future of the Federal Reserve. Cambridge: Cambridge University Press.

Calomiris, C. W., and G. Gorton. 1991. "The Origins of Banking Panics: Models, Facts, and Bank Regulation.” In R. G. Hubbard, ed., Financial Markets and Financial Crises. Chicago, Ill.: University of Chicago Press.

Calomiris, C. W., and J. R. Mason. 2003. "Fundamentals, Panics, and Bank Distress during the Depression." American ECONOMIC Review 93, no. 5 (December): 1615-47.

_ 2008. "Resolving the Puzzle of the Underissuance of National Bank Notes." Explorations in Economic History 45, no. 4 (September): 327-55.

Chandler, L. V. 1958. Benjamin Strong, Central Banker. Washington, D.C.: Brookings Institution.

Clouse, J. 1994. "Recent Developments in Discount Window Policy." Federal Reserve Bulletin (November): 965-77. 


\section{References (Continued)}

Committee on Banking and Currency. 1913. "A Bill to Provide for the Establishment of Federal Reserve Banks, for Furnishing an Elastic Currency, Affording Means of Rediscounting Commercial Paper, and to Establish a More Effective Supervision of Banking in the United States, and for Other Purposes." Hearing before the Committee on Banking and Currency on H.R. 7837 (S. 2639), U.S. Senate, 63rd Congress, 1st session, September 24, 26.

1921. "War Finance Corporation." Hearings before the Committee on Banking and Currency on the Bill S. 1915, U.S. House of Representatives, 77th Congress, 1st session, August 9.

1922. "Senate Bills to Provide Credit Facilities for the Agricultural and Livestock Industries in the United States; to Amend the Federal Farm Loan Act; to Amend the Federal Reserve Act; and for Other Purposes." Hearings before the Committee on Banking and Currency on Rural Credits, U.S. Senate, 67 th Congress, 4th session, December 30.

Committee on Finance. 1918. "Establishment of a War Finance Corporation." Hearings before the Committee on Finance on H.R. 9499, U.S. Senate, 65th Congress, 2nd session, February 8.

Committee on Ways and Means. 1918. "War Finance Corporation [Part 1]." Hearings before the Committee on Ways and Means on H.R. 9499. U.S. House of Representatives, 65th Congress, 2nd session, February 18-19.

Eichengreen, B. 1992. Golden Fetters: The Gold Standard ANd the Great Depression, 1919-1939. New York: Oxford University Press.

Federal Reserve Bank of New York. Various Dates. Circulars. New York, N.Y..

_ 2008. "Statement on Financing Arrangement of JPMorgan Chase's Acquisition of Bear Stearns." Press release issued on March 24. http://www.newyorkfed.org/newsevents/news/ markets/2008/rp080324.html.

Fettig, D. 2002. “Lender of More Than Last Resort.” Federal Reserve Bank of Minneapolis The Region, December. https://www.minneapolisfed.org/publications/the-region/ lender-of-more-than-last-resort.

Friedman, M., and A. J. Schwartz. 1963. A Monetary History of the United States, 1867-196o. Princeton, N.J.: Princeton University Press.
Garbade, K. D. 2012. Birth of A Market. Cambridge, Mass.: MIT Press.

Geithner, T. F. 2008. "Actions by the New York Fed in Response to Liquidity Pressures in Financial Markets." Testimony before the U.S. Senate Committee on Banking, Housing, and Urban Affairs, Washington, D.C., on April 3, 2008. http://www.newyorkfed.org/ newsevents/speeches/2008/gei080403.html.

Glass, C. 1927. An Adventure in Constructive Finance. Garden City, N.Y.: Doubleday, Page and Co.

Glass, C. 1932. Letter from Carter Glass to Charles Hamlin, July 25, 1932. University of Virginia, Carter Glass Papers, 1858-1949, Box 299, Section B.

Government Accountability Office. 2011. "Federal Reserve System: Opportunities Exist to Strengthen Policies and Processes for Managing Emergency Assistance." July. http://www.gao.gov/ highlights/d11696high.pdf.

Hackley, H. H. 1973. Lending Functions of the Federal Reserve BAnks: A History. Washington, D.C.: Board of Governors of the Federal Reserve System.

Hamlin, C. 1932. Letter from Charles Hamlin to Carter Glass, July 9, 1932. University of Virginia, Carter Glass Papers, 1858-1946, Box 305, Section A.

1932. Letter from Charles Hamlin to Carter Glass, July 23, 1932. University of Virginia, Carter Glass Papers, 1858-1946, Box 299, Section B.

Hepburn, A. B. 1908. "Government Currency vs. Bank Currency." The Currency Problem and the Present Financial Situation: A Series of Addresses Delivered at Columbia University 1907-1908. New York, N.Y.: Columbia University Press.

Hoover, H. 1931a. "Statement on Financial and Economic Problems." Remarks read to a group of New York bankers at the home of Secretary of the Treasury Andrew Mellon on October 4. http://www.presidency.ucsb.edu/ws/?pid=22825.

1931b. "Annual Message to the Congress on the State of the Union." Remarks given on December 8. http://www.presidency .ucsb.edu/ws/?pid=22933. 


\section{REFERENCES (CONTINUED)}

1932a. "Statement about Signing the Reconstruction Finance Corporation Act." Remarks given on January 22. http://www .presidency.ucsb.edu/ws/?pid=23210.

1932b. "Statement on Signing the Federal Reserve Act, Amendments." Remarks given on February 27. http://www .presidency.ucsb.edu/ws/?pid=23466.

1932c. "Statement on the Economic Recovery Program." Remarks given on May 12. http://www.presidency.ucsb .edu/ws/?pid=23085.

1932d. "Statement on Emergency Relief and Construction Legislation.” Remarks given on May 27. http://www.presidency .ucsb.edu/ws/?pid=23114.

1932e. "Statement on Emergency Relief and Construction Legislation.” Remarks given on July 6. http://www.presidency .ucsb.edu/ws/?pid=23152.

1932f. "Veto of the Emergency Relief and Construction Bill." Remarks given on July 11. http://www.presidency.ucsb.edu/ ws/?pid=23157.

1952. The Memoirs of Herbert Hoover: The Great

DePression 1929-1941, vol. 3. New York, N.Y.:

The Macmillan Company.

Humphrey, T. M. 1982. “The Real Bills Doctrine.” Federal Reserve Bank of Richmond Economic Review 68, no. 5 (September/October): 3-13.

2010. "Lender of Last Resort: What It Is, Whence It Came, and Why the Fed Isn't It." Cato Journal 30, no. 2 (Spring/Summer): 333-64.

Kemmerer, E. W. 1910. "Seasonal Variations in the Relative Demand for Money and Capital in the United States." National Monetary Commission. Senate Document 588. U.S. Senate, 61 st Congress, 2nd session.

Mehra, A. 2010. "Legal Authority in Unusual and Exigent Circumstances: The Federal Reserve and the Financial Crisis." University of Pennsylvania Journal of Business LAW 13, no. 1: 221-73.
Meltzer, A. H. 2003. A History of the Federal Reserve, Volume 1: 1913-1951. Chicago, Ill.: University of Chicago Press.

Mengle, D. L. 1993. “The Discount Window.” In T. Q. Cook and R. K. Laroche, eds., Instruments of the Money Market, 7th ed. Richmond, Va.: Federal Reserve Bank of Richmond. http://www.richmondfed.org/publications/research/special_reports/ instruments_of_the_money_market/pdf/full_publication.pdf.

Meyer, E. 1933. Letter from Eugene Meyer to Carter Glass. March 14, 1933. University of Virginia, Carter Glass Papers, 1858-1946, Box 5, Section A.

Mints, L. W. 1945. A History of Banking Theory in Great Britain And the United States. Chicago, Ill.: University of Chicago Press.

Nash, G. D. 1959. "Herbert Hoover and the Origins of the Reconstruction Finance Corporation.” Mississippi VALLEY Historical Review 46, no. 3 (December): 455-68.

Olson, J. S. 1977. Herbert Hoover and the Reconstruction Finance Corporation, 1931-1933. Ames, Iowa: Iowa State University Press.

Page, D. 1997. “Carter Glass.” Federal Reserve Bank of Minneapolis The Region 11, no. 3.

Putnam, G. E. 1916. “The Federal Farm Loan Act.” American Economic Review 6, no. 4: 770-89.

Radford, G. 2013. The Rise of the Public Authority: Statebuilding and Economic Development in TwentiethCentury America. Chicago: University of Chicago Press.

Saulnier, R. J., H. G. Halcrow, and N. H. Jacoby. 1958. Federal Lending and Loan Insurance. Princeton, N.J.: Princeton University Press.

Schwartz, A. J. 1999. "Is There a Need for an International Lender of Last Resort?" Cato Journal 19, no. 1 (Spring/Summer): 1-6.

Silber, W. L. 2007. When Washington Shut Down Wall Street. Princeton, N.J.: Princeton University Press.

Silber, W. L. 2009. "Why Did FDR's Bank Holiday Succeed?" Federal Reserve Bank of New York Economic Policy Review 15, no. 1 (July): 19-30. 


\section{References (Continued)}

Sprague, O. M. W. 1910. "History of Crises under the National Banking System." National Monetary Commission. Senate Document 538. U.S. Senate, 61st Congress, 2nd Session.

Sprague, O. M. W. 1914. "The Federal Reserve Act of 1913." QuARTERly Journal of ECONOMICs 28, no. 2: 213-54.

Subcommittee of the Committee on Banking and Currency. 1931. "Creation of a Reconstruction Finance Corporation." Hearings before the Committee on Banking and Currency on S.1., a Bill to Provide Emergency Financing Facilities for Banks and Other Financial Institutions and Other Purposes, U.S. Senate, 72nd Congress, 1st session, December 30.

Timberlake, $R$. H. 1978. The Origins of Central Banking in the United States. Cambridge, Mass.: Harvard University Press.
U.S. Treasury Department. 1917. Annual Report of the Secretary of the Treasury for the Year 1917. Washington, D.C.

War Finance Corporation. 1918-1929. ANNUAL RePORT of the War Finance Corporation. Washington, D.C.

Warburg, P. M. 1910. “The Discount System in Europe.” National Monetary Commission, v. 12, Senate doc. 402, 61st Congress, 2nd session.

Welton. A. D. 1925. "Agricultural Credit Facilities-Are They Ample?" Annals of the American Academy of Political AND Social SCIEnCe 117 (January): 69-77.

The views expressed are those of the author and do not necessarily reflect the position of the Federal Reserve Bank of New York or the Federal Reserve System. The Federal Reserve Bank of New York provides no warranty, express or implied, as to the accuracy, timeliness, completeness, merchantability, or fitness for any particular purpose of any information contained in documents produced and provided by the Federal Reserve Bank of New York in any form or manner whatsoever. 